\title{
The Interactions of $\mathrm{H}_{2} \mathrm{TMPyP}$, Analogues and Its Metal Complexes with DNA G-Quadruplexes-An Overview
}

\author{
Catarina I. V. Ramos ${ }^{1, *(\mathbb{D}}$, Ana R. Monteiro ${ }^{1,2} \mathbb{E}^{\mathbb{D}}$, Nuno M. M. Moura ${ }^{1} \mathbb{(}$, Maria Amparo F. Faustino ${ }^{1} \mathbb{D}^{\mathbb{D}}$, \\ Tito Trindade ${ }^{2}$ (D) and Maria Graça P. M. S. Neves ${ }^{1}$ (D) \\ 1 LAQV-REQUIMTE, Department of Chemistry, University of Aveiro, 3810-193 Aveiro, Portugal; \\ anarita.rvcm@ua.pt (A.R.M.); nmoura@ua.pt (N.M.M.M.); faustino@ua.pt (M.A.F.F.); \\ gneves@ua.pt (M.G.P.M.S.N.) \\ 2 CICECO-Aveiro, Institute of Materials, Department of Chemistry, University of Aveiro, \\ 3810-193 Aveiro, Portugal; tito@ua.pt \\ * Correspondence: c.ramos@ua.pt; Tel.: +351-234-370-692
}

check for updates

Citation: Ramos, C.I.V.; Monteiro, A.R.; Moura, N.M.M.; Faustino, M.A.F.; Trindade, T.; Neves, M.G.P.M.S. The Interactions of $\mathrm{H}_{2} \mathrm{TMPyP}$, Analogues and Its Metal Complexes with DNA G-Quadruplexes-An Overview. Biomolecules 2021, 11, 1404. https:// doi.org/10.3390/biom11101404

Academic Editor: Supriyo Bhattacharya

Received: 28 August 2021

Accepted: 22 September 2021

Published: 25 September 2021

Publisher's Note: MDPI stays neutral with regard to jurisdictional claims in published maps and institutional affiliations.

Copyright: (c) 2021 by the authors. Licensee MDPI, Basel, Switzerland. This article is an open access article distributed under the terms and conditions of the Creative Commons Attribution (CC BY) license (https:// creativecommons.org/licenses/by/ $4.0 /)$.

\begin{abstract}
The evidence that telomerase is overexpressed in almost $90 \%$ of human cancers justifies the proposal of this enzyme as a potential target for anticancer drug design. The inhibition of telomerase by quadruplex stabilizing ligands is being considered a useful approach in anticancer drug design proposals. Several aromatic ligands, including porphyrins, were exploited for telomerase inhibition by adduct formation with G-Quadruplex (GQ). 5,10,15,20-Tetrakis( $N$-methyl-4-pyridinium)porphyrin $\left(\mathrm{H}_{2} \mathrm{TMPyP}\right)$ is one of the most studied porphyrins in this field, and although reported as presenting high affinity to GQ, its poor selectivity for GQ over duplex structures is recognized. To increase the desired selectivity, porphyrin modifications either at the peripheral positions or at the inner core through the coordination with different metals have been handled. Herein, studies involving the interactions of TMPyP and analogs with different DNA sequences able to form GQ and duplex structures using different experimental conditions and approaches are reviewed. Some considerations concerning the structural diversity and recognition modes of G-quadruplexes will be presented first to facilitate the comprehension of the studies reviewed. Additionally, considering the diversity of experimental conditions reported, we decided to complement this review with a screening where the behavior of $\mathrm{H}_{2} \mathrm{TMPyP}$ and of some of the reviewed metal complexes were evaluated under the same experimental conditions and using the same DNA sequences. In this comparison under unified conditions, we also evaluated, for the first time, the behavior of the $\mathrm{Ag}^{\mathrm{II}}$ complex of $\mathrm{H}_{2} \mathrm{TMPyP}$. In general, all derivatives showed good affinity for GQ DNA structures with binding constants in the range of $10^{6}-10^{7} \mathrm{M}^{-1}$ and ligand-GQ stoichiometric ratios of 3:1 and 4:1. A promising pattern of selectivity was also identified for the new $\mathrm{Ag}^{\mathrm{II}}$ derivative.
\end{abstract}

Keywords: aromatic ligands; porphyrins; metalloporphyrins; $\mathrm{H}_{2} \mathrm{TMPyP}$; $\mathrm{Ag}^{\mathrm{II}} \mathrm{TMPyP}$; G-quadruplexes; telomerase inhibition; selectivity

\section{Introduction}

The discovery of telomeres was reported first by H. Muller in 1938 and soon after, in 1941, by McClintock [1-3]. In these earliest studies, both authors showed that each chromosome end is limited by a structure called telomere. The main functions of this type of structures are: (i) to maintain the stability of the structure of the chromosomes; (ii) to ensure that the genetic information is perfectly copied when the cell duplicates and (iii) to prevent the end junction between consecutive chromosomes which can lead to deoxyribonucleic acid (DNA) degradation or genetic mutations and consequently to the appearance of tumors [2].

Further studies demonstrated that during the process of cell division, telomeres undergo shortening since interruptions in the DNA replication process occur. As a defense 
to the mechanism involved in telomeres shortening, the enzyme telomerase was identified [2,4]. Telomerase is an enzyme that consists of several components including an endogenous ribonucleic acid (RNA) template of eleven nucleotides and a reverse transcriptase that adds specific and repetitive DNA sequences to the $3^{\prime}$ end of the chromosomes, preventing their shortening [2]. A requisite for telomerase activity is the existence of the single-strand DNA, to which the RNA template is connected by complementarity and then allows telomerase to perform its function of telomeric repeat addition (Figure 1).

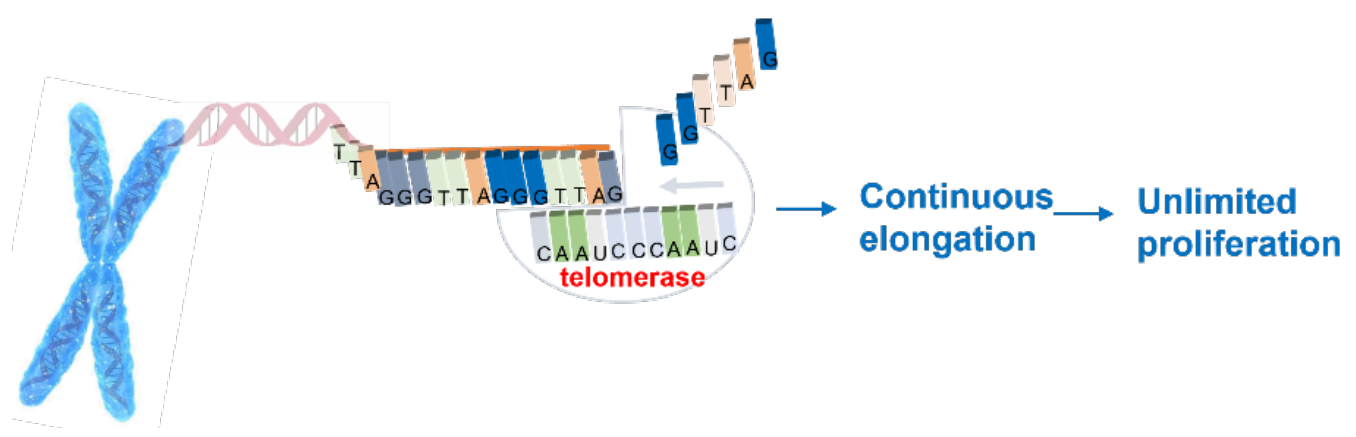

Figure 1. Telomerase function.

The proposal of the enzyme telomerase as a potential target for anticancer drug design results from the evidence that this enzyme is overexpressed in almost $90 \%$ of human cancers $[5,6]$.

Other important targets for anti-cancer drug design are human oncogenes and tumor suppressor genes due to their close association with the appearance of cancer cells. Oncogenes can result from the mutation of proto-oncogenes, the genes responsible for normal cell division, stimulation and death. Therefore, oncogenes involved in the initiation and progression of tumors have also been recognized as targets for the development of new anticancer drugs $[7,8]$. An interesting discussion concerning the challenges and potential advantages of targeting telomeric G-quadruplex (GQ) compared to gene promoter Gquadruplexes and to protein or enzyme targets was reported by Balasubramanian et al. [7].

The presence of repetitive sequences of the nucleobases thymine (T), adenine (A) and guanine $(\mathrm{G})$, in the sequence TTAGGG (abbreviated as $\mathrm{T}_{2} \mathrm{AG}_{3}$ ), and of secondary structures, such as the G-quadruplexes (GQ) at the end of telomeres (whose function is to protect telomere ends from nuclease attack) enables indirect targeting of telomerase [9-11]. GQ are higher-order DNA structures formed by the self-assembly of four guanine $(G)$ bases in a planar quadrangular arrangement via Hoogsteen hydrogen bonding, known as G-quartets (Figure 2). The subsequent stacking of these quartets on top of each other via $\pi-\pi$ interactions can give rise to different GQ conformations, as is exemplified in Figure 2 for an intermolecular (bimolecular) GQ conformation [12].

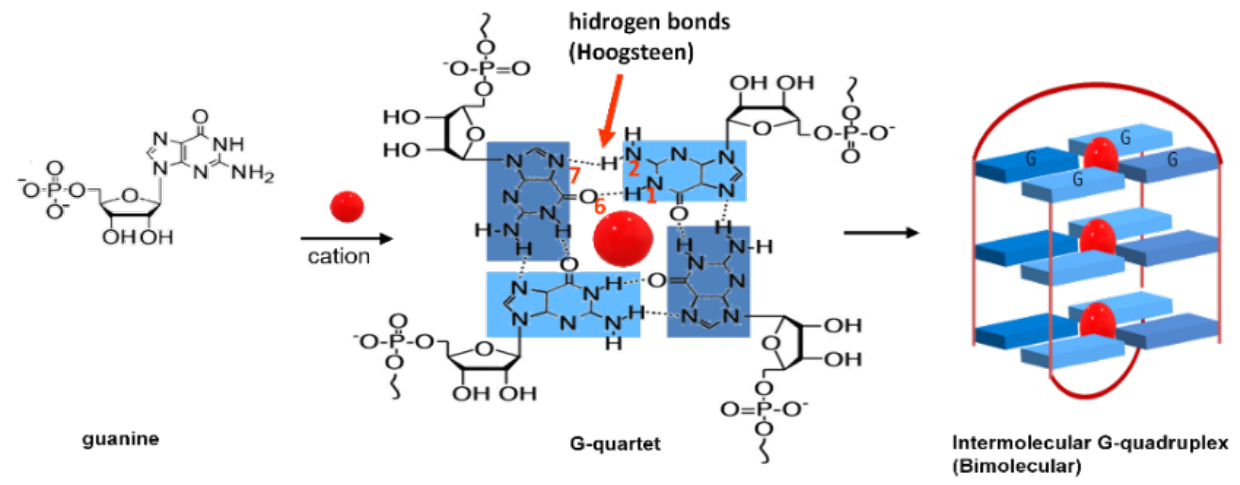

Figure 2. G-quartet and a possible G-quadruplex structure. 
The stability of the GQ structures depends on the presence of cations, whose location results from a balance between cation repulsion and attractive interactions with oxygen atoms from carbonyl groups.

Ions such as $\mathrm{NH}_{4}{ }^{+}$and $\mathrm{K}^{+}$with ionic radii (i.r.) of $1.43 \AA$ and $1.33 \AA$, respectively, are too bulky to coordinate within the plane of a G-quartet, thus their coordination occurs with eight oxygen atoms between two stacked G-quartets (Figure 3A). In the case of cations with a small ionic radius, such as $\mathrm{Na}^{+}$(i.r. $0.95 \AA$ ), the coordination with four oxygen atoms within the plane of a single quartet is possible (Figure 3B).

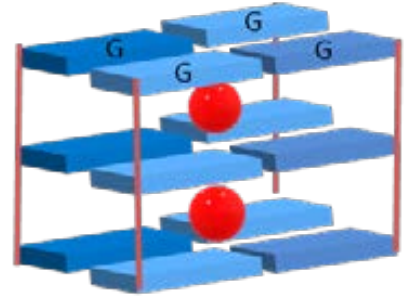

A

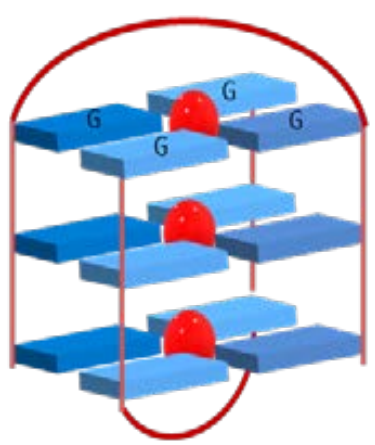

B

Figure 3. Cation positions between stacked quartets (A) or within the plane (B) in a G-quadruplex containing three quartets (for simplicity, backbones were omitted).

Depending on the number of DNA strands involved in the GQ arrangement, conformations mediated by intra- or intermolecular interactions are formed. Structures formed from one, two or four separate strands of DNA give rise, respectively, to GQ in uni-, bior tetramolecular conformations $[13,14]$. The GQ structures are also dependent on the spatial orientation of the strands and are designated as parallel, antiparallel or hybrid depending on the relative strand orientation (Figure 4A). The formation and stability of all unimolecular (intramolecular) and bimolecular (intermolecular) GQ structures imply the presence of three or four loops with different sizes and sequences. The single-strand sections that are not involved in the G-quartet arrangement form loops that link the guanines bases. These loops can adopt different geometries, namely edgewise (or lateral), double-chain-reversal (or propeller) and diagonal (Figure 4B). The loop residues can further stabilize GQ structures through hydrogen bonds and by stacking interactions.

A

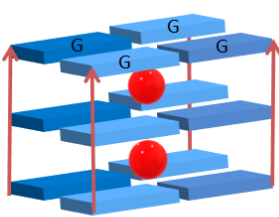

Paralell $\uparrow \uparrow \uparrow \uparrow$

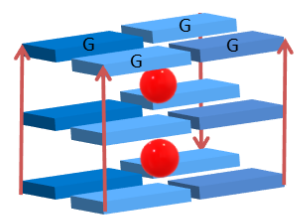

3+1 hybrid $\uparrow \uparrow \uparrow \downarrow$

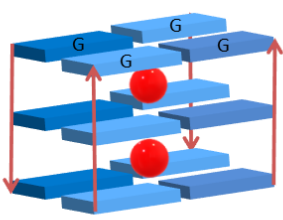

Antiparalell $\uparrow \uparrow \downarrow \downarrow$

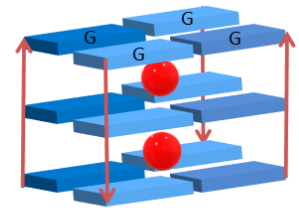

Antiparalell $\uparrow \downarrow \uparrow \downarrow$

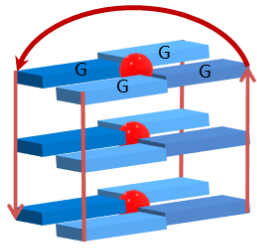

Diagonal loop

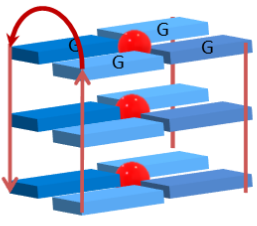

Edgewise loop

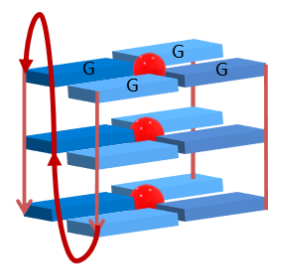

Double chain reversal loop

Figure 4. (A) Different conformations assumed by G-quadruplexes structures depending on strand orientation and (B) possible loop geometries. 
The relative strand orientation also influence the glycosidic bond angle of the guanines involved in the quartets that can assume an anti and/or syn geometry (Figure 5). A combination of syn and anti geometries is observed for antiparallel and hybrid structures, while parallel topologies contain almost exclusively anti geometry (Figure 5) [15,16].

All the described structural properties of GQ concerning not only the length, base composition and directionality of the loops, but also the size of the stabilizing metal cations, contribute to the existence of four grooves surrounded by the guanine phosphodiester backbone [17]; these cavities are similar to the minor and major grooves formed in the well-known double-stranded structure. In the GQ grooves, large variations in the widths, depths, inter-phosphate distances between the DNA strands and base orientations are also found (Figure 5).

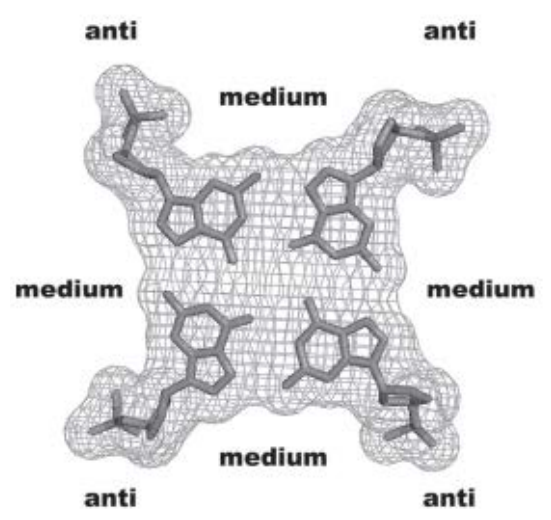

Parallel G-quadruplex

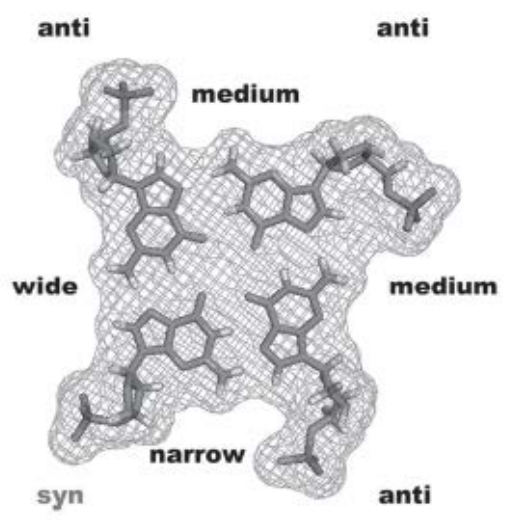

Anti-parallel G-quadruplex

Figure 5. Anti and syn conformation of glycosidic torsion angles and groove sizes of parallel and anti-parallel GQ structures, (figure reused from [18], with permission from John Wiley and Sons.

Changes in strand direction also affect the guanine glycosidic torsion angles and will further alter the relative position of the sugar ribose and the groove dimension. In the case of parallel GQ, all the guanine glycosidic torsion angles are characteristic of an equivalent anti conformation, thus the four grooves' dimensions are all equivalent. If one of the strand orientations changes to an antiparallel arrangement, changes in guanine glycosidic torsion angles occur and adopt both syn and anti conformations. These changes will further alter the groove dimensions, generating narrow, medium and wide grooves (Figure 5).

In the case of human telomeric DNA, the tandem repeats until the sequence $T_{2} A_{3}$ form unimolecular intramolecular G-quadruplexes in the chromosomic end regions.

The recognition that GQ structures can be easily accessible in physiological conditions in the presence of monovalent cations such as $\mathrm{NH}_{4}{ }^{+}, \mathrm{Na}^{+}$and $\mathrm{K}^{+}$[19] was of particular value in the wide range of studies involving the investigation of GQ as targets for drug design [13,20-22].

It has been found that G-quadruplexes are recognized and partially unwound by telomerase for $3^{\prime}$-end extension, thus the binding of stabilizing compounds to G-quadruplex structures will "lock" the telomeres in the G-quadruplex configuration, preventing telomere lengthening by telomerase (Figure 6) [23].

Telomerase inhibitors should present higher selectivity for GQ DNA structures when compared with duplex DNA as the drug must be able to recognize GQ DNA in the presence of a large amount of duplex DNA, in the cellular nucleus. The interaction of the ligand with duplex will reduce its availability to bind GQ structures, resulting in a reduction of its telomerase inhibitory function [24].

The importance of developing ligands with adequate structural features to selectively stabilize GQ DNA structures in the presence of duplex DNA structures prompted us to discuss some important achievements concerning this topic. 

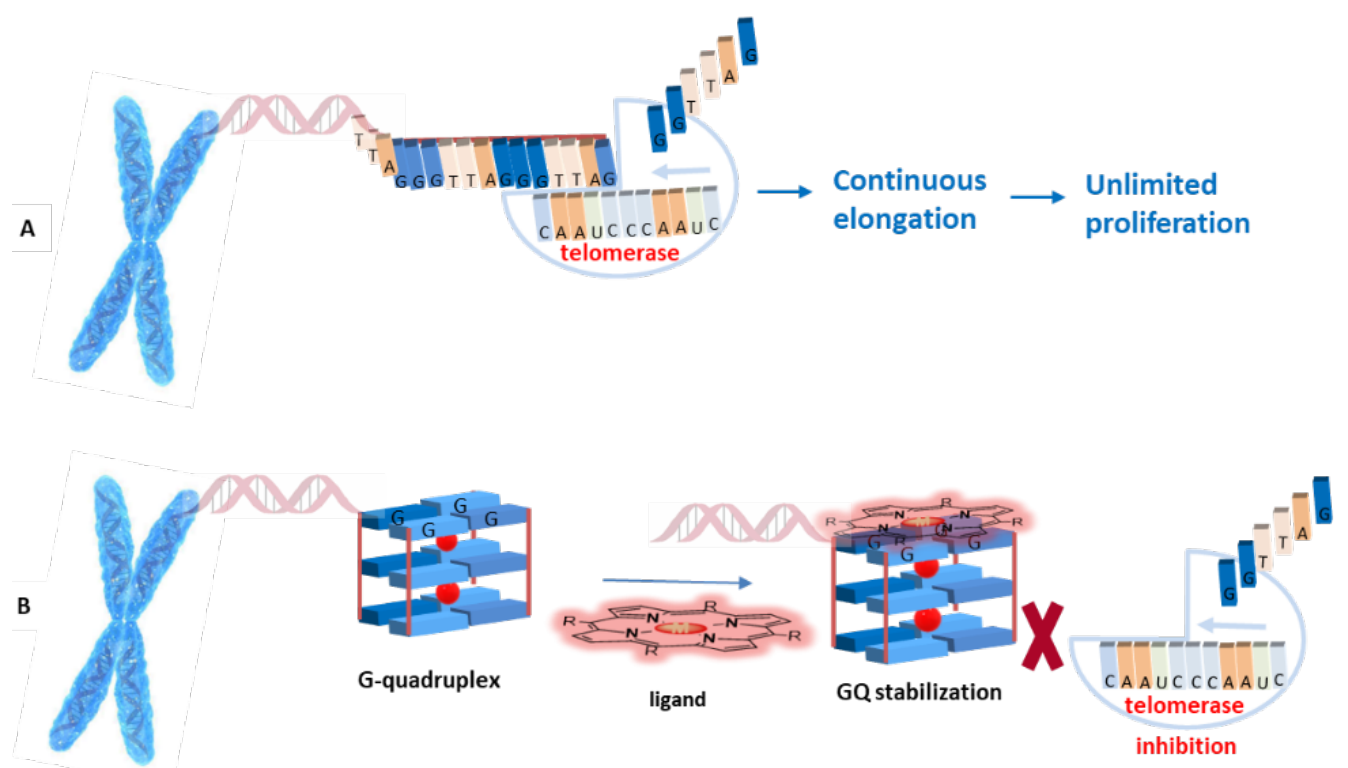

Figure 6. (A) Telomere end elongation by telomerase; (B) G-quadruplex-ligand adduct formation for indirect telomerase inhibition.

Special attention will be given to the interactions of the positively charged ligand 5,10,15,20-tetrakis ( $N$-methyl-4-pyridinium)porphyrin $\left(\mathrm{H}_{2} \mathrm{TMPyP}\right)$ with several DNA sequences able to form GQ and duplex structures. The impact of $\mathrm{H}_{2} \mathrm{TMPyP}$ complexation with different metal ions (e.g., $\mathrm{Zn}^{\mathrm{II}}, \mathrm{Co}^{\mathrm{III}}, \mathrm{Ni}^{\mathrm{II}}, \mathrm{Cu}^{\mathrm{II}}, \mathrm{Pd}^{\mathrm{II}}, \mathrm{Au}^{\mathrm{III}}$ and $\mathrm{Mn}^{\mathrm{III}}$ ) in the ligand selectivity towards GQ structures will be also considered and, when adequate, the reference to other studies concerning analogues to $\mathrm{H}_{2} \mathrm{TMPyP}$ will also be presented.

In the selection of this issue, we have our interest in the synthesis, functionalization and characterization of porphyrins and analogues for different biological/medical applications [25-29], namely as DNA stabilizing agents and telomerase inhibitors [30-37].

\section{Interactive G-Quadruplex Ligands and GQ Recognition Modes}

In 1997, Sun et al. reported [38], for the first time, the inhibition of telomerase by interactive G-quadruplex ligands and, based on the results, anticipated the potential of the approach as a novel research line for anticancer drug design. Since then, the search for GQ interactive ligands with high specificity and affinity for GQ has become a central issue for different research groups $[9,12,18,22,23,38,39]$.

A large number of small ligands have demonstrated ability to bind non-covalently to DNA and RNA GQ structures [9]. Most of these ligands contain several fused or nonfused aromatic rings or are aromatic macrocycles. An interesting overview of the literature highlighting structure-quadruplex interaction relationships of organic modular GQ ligands was published by Alexandra Paulo et al. [40].

Different GQ recognition modes are possible: intercalation (Figure 7A), outside stacking on the ends of the G-quartet core, also known as end-stacking (Figure 7B), and interaction with the backbone (core and loop bases) known as groove or loop binding (Figure 7C,D). Since the GQ structure is rigid and stable, the distortion triggered by the intercalation of a ligand has an energetic cost. In this way, outside stacking (Figure 7B-D) is seen as the more favorable binding mode [39].

Simple procedures using optical spectroscopic techniques like ultraviolet-visible absorption (UV-Vis), fluorescence and circular dichroism (CD) allow to evaluate the ligand affinity and selectivity to DNA structures, while other spectroscopic methods such as mass spectrometry (MS) and nuclear magnetic resonance (NMR) allow to obtain kinetic, thermodynamic, stoichiometric and conformational data in structure-activity relationship (SAR) studies [31,32,41-43]. The efficiency of several small molecules to inhibit telomerase 
by adduct formation with GQs has been studied using different methods with promising results $[30,31,44-48]$.

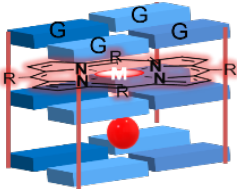

A - Intercalation

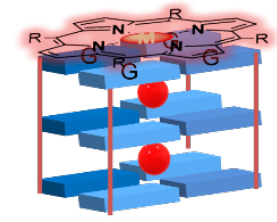

B - End-stacking

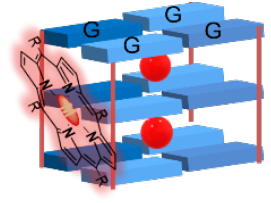

C - Groove binging

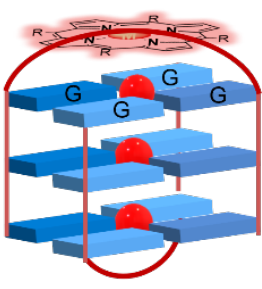

D - loop binding

Figure 7. (A-D) Types of interactions ligand-G-quadruplexes. For simplicity, grooves are not represented.

Under the context of aromatic ligands containing fused rings, the dicationic anthraquinone derivative presented in Figure 8 was the first ligand reported to inhibit telomerase function [38]. Many other small ligands were then reported to inhibit telomerase activity with small half-maximal inhibitory concentration $\left(\mathrm{IC}_{50}\right)$ values, like trisubstituted acridines (e.g., BRACO-19) [49], the perylene tetracarboxylic diimide derivative (PIPER) [50], the fluorinated polycyclic quinoacridinium cation (RHPS4) (Figure 8) and dibenzophenanthroline derivatives [51], among others [12,39,52].

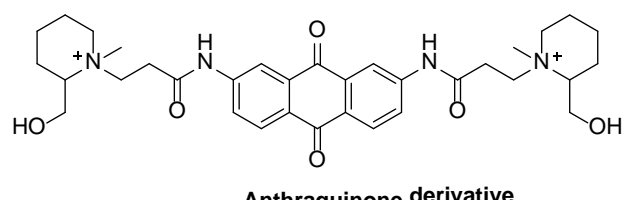

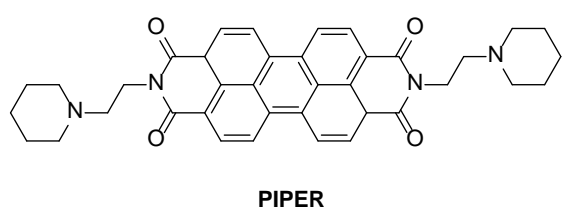

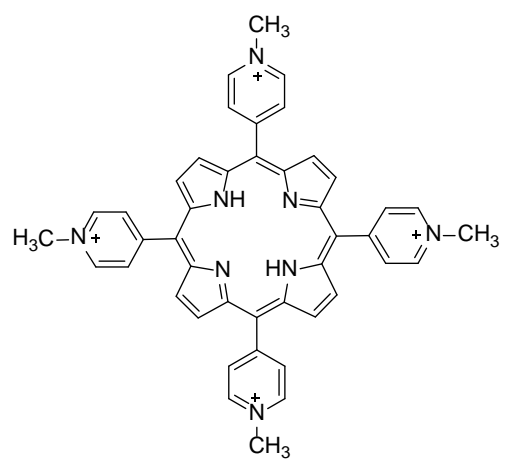

$\mathrm{H}_{2}$ TMPyP<smiles></smiles>

RHPS4<smiles></smiles>

Braco-19

Figure 8. Examples of polycyclic ligands reported to inhibit telomerase activity.

Amongst the aromatic macrocycles, porphyrins, such as the cationic $\mathrm{H}_{2} \mathrm{TMPyP}$ and analogs appear as the most widely tested telomerase inhibitors [32,33,53-55].

Structural attributes such as the presence of an extended heteroaromatic moiety that can interact on the G-quartet surface of a G-quadruplex by $\pi-\pi$ stacking, and flexible cationic charged terminal side chains are pointed as essential features for effective ligand binding to a quadruplex and optimal inhibition of telomerase activity [9]. Other important structural characteristics are the presence of bulky substituents to prevent intercalation with double-stranded DNA and good solubility in aqueous media. In general, aromatic/planar molecules such as porphyrins and analogs, especially if positively charged, present good GQ stabilizing properties with high affinity for G-quadruplexes $\left(K_{b} \geq 10^{6} \mathrm{M}^{-1}\right.$, where $K_{b}$ corresponds to the binding constant) [56-58].

Ligands containing metals present higher interaction with G-quadruplexes due to stronger $\pi-\pi$ interactions and/or coordination processes, thus being more selective for GQ $[42,59]$. A metal center can be predicted as a structural region that sets ligands in 
specific geometries, thus optimizing their binding properties. Ligands with different metal centers can assume different geometries. In addition to their structural characteristics, the presence of metal centers can reduce the electron density on coordinated aromatic ligands, increasing the strength of $\pi-\pi$ interactions with $\mathrm{G}$-quartets.

As mentioned above, in the following section special attention will be given to works where the tetracationic $\mathrm{H}_{2} \mathrm{TMPyP}$ and related porphyrins were key players and how their coordination with different metals affects the stabilization and selectivity for GQ over duplex. Moreover, the wide range of small polycyclic ligands studied in this field has been the subject of other excellent revisions $[9,40,52]$.

\section{Porphyrins and Metalloporphyrins as Interactive G-Quadruplex Ligands}

The cationic $\mathrm{H}_{2} \mathrm{TMPyP}$ is one of the most studied porphyrins in telomerase inhibition by adduct formation with telomeric GQ structures [38,56,60], and in the stabilization of non-telomeric biologically relevant GQs from human oncopromoters, bacterial genomes and viral genomes [8].

The structure of tetrapyrrolic macrocycles like porphyrins can be changed in the periphery, at the meso or $\beta$-pyrrolic positions, with several types of substituents or at the porphyrin inner core by metal coordination, affording stable metallo-based ligands [61,62].

The type of interaction between cationic porphyrins and DNA structures depends not only on the location, size and charge of peripheral substituents but also on the presence or absence of metal in the porphyrin core [14]. It has been reported that the presence, at meso positions, of pyridinium substituents not only favors interactions with DNA by $\pi-\pi$ stacking but also improves its water solubility, thus being an important feature for telomerase inhibition $[31,39,63,64]$.

Cationic porphyrins are able to interact with negatively charged phosphate groups of DNA structures, minimizing the electrostatic repulsions. Moreover, their diameter is compatible with the diameter of the central channel of GQ, thus interaction by end-stacking was described to be favorable [31].

As already mentioned, the $\mathrm{H}_{2}$ TMPyP is one of the most studied porphyrins in this field, and although reported as presenting high affinity to GQ, its poor selectivity for GQ over duplex structures is recognized [60]. To increase its selectivity, porphyrin modifications, either at the peripheral positions or at the inner core, were envisaged. The complexation of porphyrins and analogs with metals appears to be a strategy to increase porphyrin selectivity.

Izbicka et al. [65] reported for the first time the ability of metalloporphyrins to interact with G-quadruplex structures present in the telomeric sequence. These studies involved cell-based biochemical assays and molecular modeling, namely using the $\mathrm{In}^{\mathrm{III}}$ and $\mathrm{Cu}^{\mathrm{II}}$ complexes of $\mathrm{H}_{2} \mathrm{TMPyP}$ and QP4 (Figure 9). The binding mode of porphyrins and metalloporphyrins was proposed to be $\pi-\pi$ stacking, specifically end-stacking on the top of the G-quartets at the termini of the GQ structures. An enhanced binding affinity was proposed for metalloporphyrins through an additional electrostatic interaction induced by the presence of metal ions.

A study where the $\mathrm{Mn}^{\mathrm{III}}$ metal complex of the TMPyP was activated with the potassium monopersulfate $\left(\mathrm{KHSO}_{5}\right)$, an oxygen atom donor, forming a very reactive high-valent porphyrin $\mathrm{Mn}(\mathrm{V})=\mathrm{O}$ species was reported by Vialas et al. [66]. The authors reported that efficient oxidative cleavage of the quadruplex could be mediated by this oxo-metalloporphyrin. Using Polyacrylamide Gel Electrophoresis analysis (PAGE), the authors were able to identify the location of damage; the obtained results showed that the metalloporphyrin was able to bind to the last G-quartet of the quadruplex structure via an external interaction. It has been found that the high-valent oxo-metalloporphyrin was also able to mediate both electron-abstraction or $\mathrm{H}$-abstraction on guanine or thymine residues, respectively, within the GQ target.

Later, Shi et al. [67] published a scientific paper revisiting the telomerase inhibiting activity of $\mathrm{H}_{2} \mathrm{TMPyP}$ (or $\mathrm{H}_{2} \mathrm{TMPyP}_{4}$ ) and of a wide range of analogs such as $\mathrm{TMPyP}_{3}$, 
$\mathrm{TMPyP}_{2}, \mathrm{QP}_{4}$ and $\mathrm{QP}_{3}$, (Figure 9) among others. The authors were able to SAR rules related to the importance of the presence of positively charged substituents, its position at meso or beta positions and the influence of bulky substituents on the interaction with GQ. The percentage of telomerase inhibition by several complexes of $\mathrm{H}_{2} \mathrm{TMPyP}$, namely the $\mathrm{Zn}^{\mathrm{II}}, \mathrm{Co}^{\mathrm{III}}, \mathrm{Fe}^{\mathrm{III}}, \mathrm{Ni}^{\mathrm{II}}, \mathrm{Mn}^{\mathrm{III}}, \mathrm{Cu}^{\mathrm{II}}, \mathrm{Mg}^{\mathrm{II}}, \mathrm{Pt}^{\mathrm{II}}$ and $\mathrm{Pd}^{\mathrm{II}}$ ones, was also accessed using a primer extension assay. The authors found that the square planar $\mathrm{Cu}$ II complex and the pyramidal $\mathrm{Zn}^{\mathrm{II}}$ were the better inhibitors and correlated this with the unhindered face for stacking offered by these two metalloporphyrins.

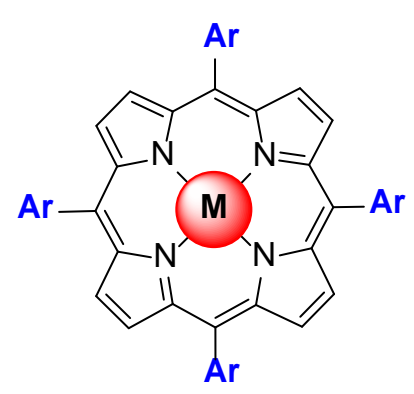

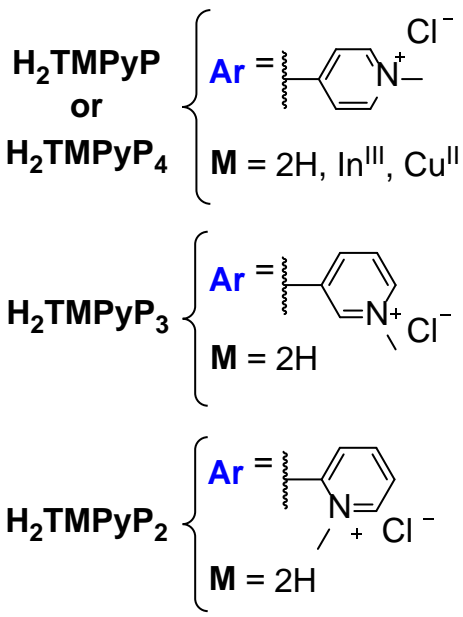
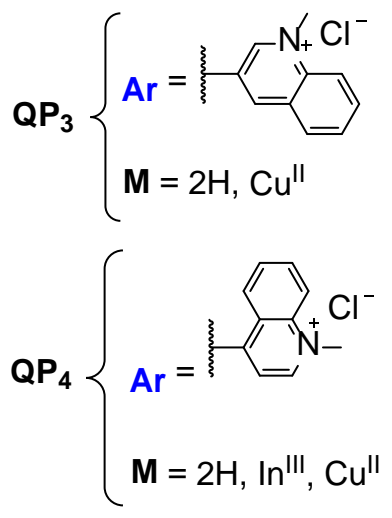

Figure 9. Structure of the first porphyrins and metalloporphyrins evaluated as GQ ligands.

The interaction of the complex $\mathrm{Cu}^{\mathrm{II}} \mathrm{TMPyP}$ with tetramolecular GQ with general sequence $\mathrm{T}_{4} \mathrm{G}_{n} \mathrm{~T}_{4},(n=4$ and 8$)$ was studied by Keating et al. [68] using the spectroscopic methods UV-Vis, fluorescence, $C D$ and electron paramagnetic resonance (EPR). A binding stoichiometric ratio of 2:1 ( $\left.\mathrm{Cu}^{\mathrm{II}} \mathrm{TMPyP}-\mathrm{GQ}\right)$ was described and end-stacking of $\mathrm{Cu}^{\mathrm{II}} \mathrm{TMPyP}$ at each end of the G-quadruplex was proposed. Similar behavior has been described for the same porphyrin complex $\mathrm{Cu} \mathrm{u}^{\mathrm{II}} \mathrm{TMPyP}$ and the $\mathrm{T}_{4} \mathrm{G}_{\mathrm{n}} \mathrm{T}_{4}$ sequence, with $n$ between 4 and 10 [69].

The $\mathrm{Cu}^{\mathrm{II}}, \mathrm{Ni}^{\mathrm{II}}, \mathrm{Zn}^{\mathrm{II}}$ and $\mathrm{Co}^{\mathrm{III}} \mathrm{TMPyP}$ derivatives were also explored in a study established to understand the effect of the coordinated metal, its geometry and of an additional positive charge (in the case of the $\mathrm{Co}^{\mathrm{III}}$ ) on the interactions of these metalloporphyrins with human telomeric GQ [70]. This study points to the existence of two binding modes, consistent with the coexistence of end-stacking and intercalation in the case of $\mathrm{Ni}^{\mathrm{II}}$ and $\mathrm{Cu}^{\mathrm{II}}$ porphyrins in a stoichiometry of $4: 1$. For $\mathrm{Zn}^{\mathrm{II}}$ and $\mathrm{Co}^{\mathrm{III}}$, the presence of axial ligands justifies the interaction occurring exclusively by end-stacking in a 2:1 stoichiometric ratio.

In 2005, Dixon et al. published a paper describing how the change in the metal coordinated in the porphyrin core influences the kinetics and its mode of interaction [71]. Considering that, under physiological conditions, the nickel porphyrins are inert concerning redox processes and are not photoactivable, it is expected that they interact with the telomeres passively by stacking processes. On the other hand, the manganese derivatives should be able to interact with telomeres and damage them by oxidative processes within cells, but stacking interactions are impossible for $\mathrm{Mn}^{\mathrm{III}}$ derivatives due to the presence of water as axial ligands.

Taking these facts into account, the binding properties of the $\mathrm{Ni}^{\mathrm{II}}$ and $\mathrm{Mn}^{\mathrm{III}}$ metalloporphyrins owning one of the meso substituents with different length and bulky elements (compounds 2 and 3, Figure 10) were studied by surface plasmon resonance (SPR), and the capacity of the $\mathrm{Ni}^{\mathrm{II}} \mathrm{TMPyP}$ to inhibit telomerase was also evaluated by a telomeric repeat amplification protocol (TRAP) assay. It has been found that the nature of the metal influences not only the kinetics but also the ligand binding mode. Higher selectivity, a tenfold preference for quadruplex over duplex, was observed for $\mathrm{Mn}^{\mathrm{III}} \mathrm{TMPyP}$ [71]. The 
authors also showed that the kinetics of drug interaction with GQ DNA seems to depend on the mode of binding — end-stacking vs. external binding - in the GQ grooves.

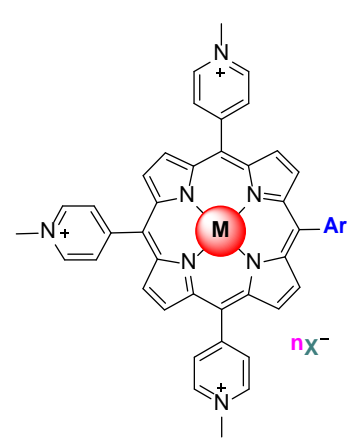

$1 \quad M=N i^{l l} ; n=4 ; X=C l$

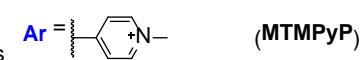

2

$\mathbf{M}=\mathrm{Nill} ; n=3 ; \mathbf{X}=\mathrm{Cl}$

$\mathbf{M}=\mathrm{Mn}^{\mathrm{III}} ; \mathrm{n}=4 ; \mathrm{X}=\mathrm{Cl}$<smiles>CC(C)([Al]=[Zn])c1ccc(OCCCCC(=O)NCCCNCCCN)cc1</smiles>

3

$\mathbf{M}=\mathrm{Nill} ; \mathrm{n}=3 ; \mathrm{X}=\mathrm{Cl}$

$M=M n^{\text {III: }} n=4 ; X=C l$<smiles>CC(C)(C=[18O])c1ccc(OCCCCC(=O)NCCCCNc2ccnc3cc(Cl)ccc23)cc1</smiles>

4
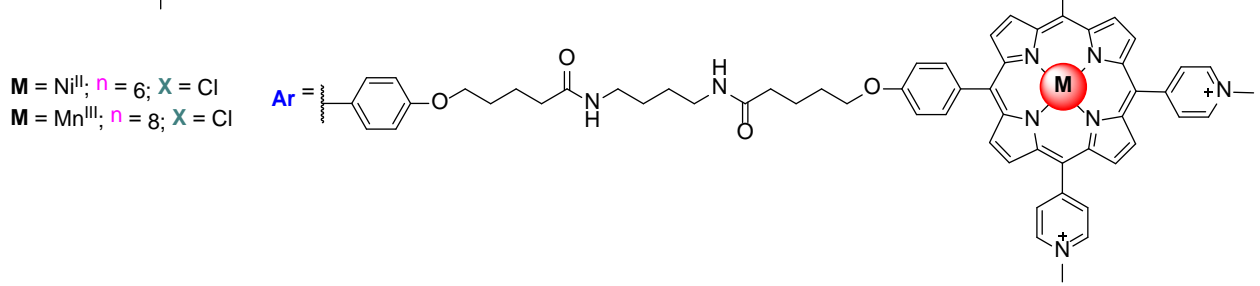

Figure 10. Structure of the $\mathrm{Ni}^{\mathrm{II}}$ and $\mathrm{Mn}{ }^{\mathrm{III}}$ porphyrins derivatives studied by Dixon et al. [71].

The kinetic constants for the association and dissociation of different porphyrins with duplex and quadruplex DNA were obtained and depending on the kinetic mode (slow or fast) different types of interaction were proposed.

An aromatic moiety that can interact, by stacking, with DNA is present in the porphyrins that presented fast kinetics. The Mn ${ }^{\text {III }}$ porphyrin derivatives (compounds 1, 2 and 4, Figure 10) showed slow kinetics that were explained either by the perturbation of the coordination sphere of the metal ion upon interaction with DNA, or, more likely, by a binding mode that is different from stacking (external binding).

Later, the same research group published a communication reporting the ability of a $\mathrm{Mn}^{\mathrm{III}}$ pentacationic porphyrin to discriminate, by four orders of magnitude, the quadruplex from the duplex structures, probably as a result of combining in its structure a central aromatic core and four flexible cationic arms [72]. The study was performed using SPR to measure the noncovalent equilibrium binding constants and the TRAP assay. The authors suggested that the bulky cationic substituents surrounding the aromatic core of the ligand could be responsible for its poor affinity for duplex DNA. The hypothesis of the occurrence of interaction by stacking with the last tetrad of quadruplex DNA by loss of one axial ligand or fitting of an axial water ligand within the central ion channel was also presented.

Another study involving $\mathrm{Ni}^{\mathrm{II}} \mathrm{TMPyP}, \mathrm{Mn}^{\mathrm{III}} \mathrm{TMPyP}, \mathrm{Co}{ }^{\mathrm{III}} \mathrm{TMPyP}$ and $\mathrm{Au}^{\mathrm{III}}$ TMPyP was later described [60]. $\mathrm{H}_{2}$ TMPyP analogs with bulky substituents were also studied. From the $\mathrm{CD}$, fluorescence, SPR, telomerase assay and in vitro experiments, the authors revealed that the porphyrins with $\mathrm{Mn}^{\mathrm{III}}$ and $\mathrm{Co}^{\mathrm{III}}$ present lower stabilization properties towards $\mathrm{G}_{3}\left(\mathrm{TTAG}_{3}\right)_{3}$ when compared to the free base, $\mathrm{Ni}^{\mathrm{II}}$ and $\mathrm{Au}^{\mathrm{III}}$ porphyrins (Figure 11). 


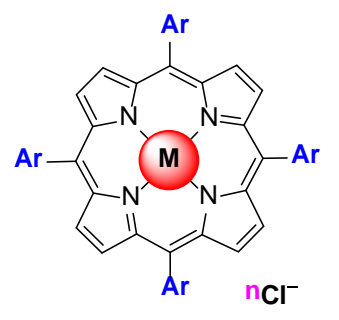

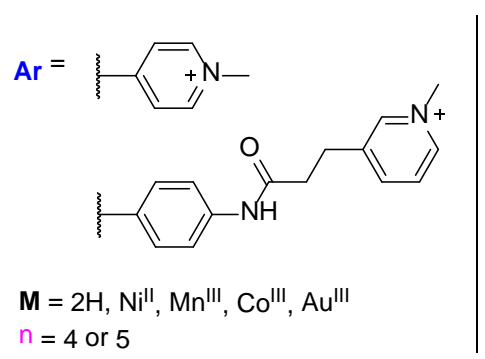

A

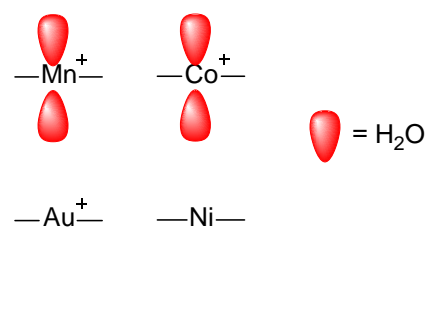

Figure 11. Structure of $\mathrm{H}_{2} \mathrm{TMPyP}$ and analogs with bulky substituents (A); presence or absence of axial substituents in different metal ions (B) studied by Romera et al. [60].

The presence of water molecules on either side of the porphyrin core of Mn ${ }^{\mathrm{III}} \mathrm{TMPyP}$ and $\mathrm{Co}^{\mathrm{III}} \mathrm{TMPyP}$ (Figure 11B) was pointed out as a factor that prevents the porphyrin intercalation between the base pairs of DNA and, consequently, decreases the porphyrins binding affinity to double-stranded DNA. On the other hand, the authors revealed that axial water molecules might hinder the initial stacking of the porphyrin molecule at the G-quadruplex end. The in vitro cellular tests performed with free-base and Mn ${ }^{\mathrm{III}} \mathrm{TMPyP}$ analogs containing bulky substituents showed that these ligands can penetrate cells and mediate some of the typical cellular effects of small GQ ligands.

A porphyrin scaffold, the 5,10,15,20-tetrakis(4-(1-methylpyridinium-2-yl)phenyl)porphyrin $\left(\mathrm{H}_{2} \mathrm{TMPy}_{2} \mathrm{PP}\right.$, Figure 12$)$ and its metal complexes with $\mathrm{Ni}^{\mathrm{II}}, \mathrm{Co}^{\mathrm{III}}$ and $\mathrm{Mn}^{\mathrm{III}}$ were studied, aiming to evaluate the impact of the variation of the charge position and axial coordination in the center of the porphyrin in the binding affinity of the selected complexes. The $\mathrm{MTMPy}_{2} \mathrm{PP}$ derivatives were studied in the presence of GQ and duplex DNA structures using fluorescence resonance energy transfer (FRET), CD, SPR and NMR methods [73]. The authors conclude that the interaction with GQ of all the derivatives, even of the $\mathrm{CO}^{\mathrm{III}}$ complex coordinated with two water molecules, occurs by a $\pi$-stacking-like mode with an external G-quartet. Later, Dejeu et al. [74] extended the previous study to the $\mathrm{Ni}^{\mathrm{II}}, \mathrm{Co}^{\mathrm{III}}$ and $\mathrm{Mn}^{\mathrm{III}}$ complexes of the 5,10,15,20-tetrakis(4-guanidinophenyl)porphyrin (MTGP) (Figure 12).

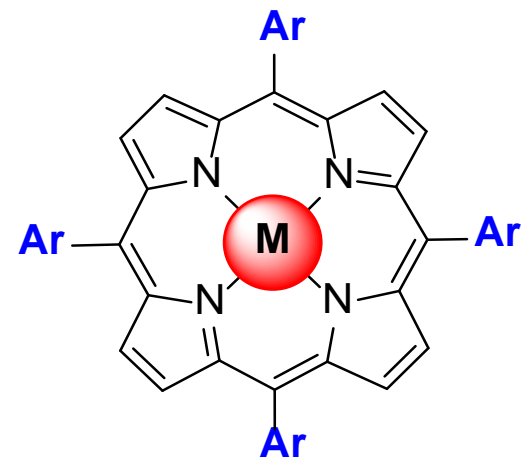

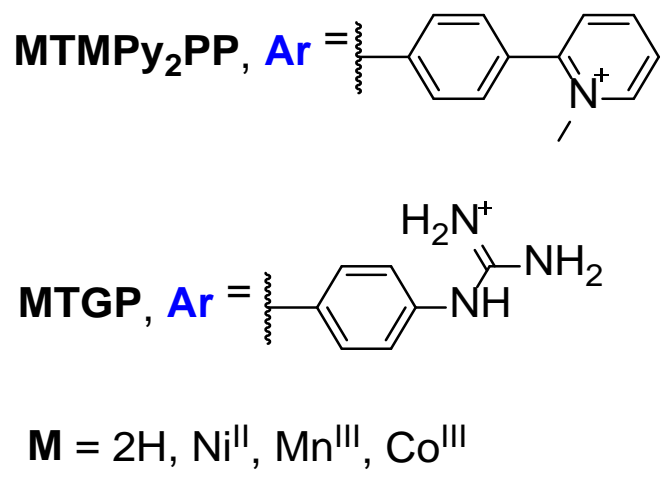

Figure 12. Structures of 5,10,15,20-tetrakis(4-(N-methyl-pyridinium-2-yl)phenyl)-porphyrin (MTMPy $2 \mathrm{PP}$ ) and 5,10,15,20-tetrakis(4-guanidinophenyl)porphyrin (TGP) derivatives, studied by Sabater et al. [73].

The results obtained for these two series of metalloporphyrins based on the ligands MTGP and MTMPy 2 PP were then compared with those reported for the corresponding $\mathrm{H}_{2}$ TMPyP. The authors noted that, when compared to the metalated MTMPyP porphyrin series, it is striking that the influence of the metal is completely different. From this study, the authors conclude that the MTGP and $\mathrm{MTMPy}_{2} \mathrm{PP}$ porphyrins were better GQ ligands than their MTMPyP counterparts and, on the contrary to the $\mathrm{H}_{2} \mathrm{TMPyP}$ metal derivatives, the metal had no influence on the observed dissociation constant $\left(\mathrm{K}_{\mathrm{D}}\right)$ values. 
$\mathrm{Zn}^{\mathrm{II}} \mathrm{TMPyP}$ was also explored in an interesting work where its interaction with a quadruplex structure stabilized by the unusual presence of lead ion (Pb-GQ) (Figure 13) was evaluated using CD and UV-Vis spectroscopy and mass spectrometry [75]. The Pb-GQ structure was found to be formed in a 1:1 stoichiometry ( $\left(\mathrm{Pb}^{\mathrm{II}}-\mathrm{GQ}\right)$. The $\mathrm{Zn}^{\mathrm{II}} \mathrm{TMPyP}$ was described as a Pb-GQ structure-stabilizing ligand. The steric hindrance of the axial ligand of $\mathrm{Zn}^{\mathrm{II}}$ and the relatively rigid structure of $\mathrm{Pb}-\mathrm{GQ}$ was pointed out as factors that precluded the ligand intercalation and an interaction exclusively by end-stacking was proposed.

Aiming to understand the mechanism of ligand-assisted GQ folding, the potential of $\mathrm{H}_{2} \mathrm{TMPyP}$, and of its $\mathrm{Zn}^{\mathrm{II}}, \mathrm{Cu}^{\mathrm{II}}$ and $\mathrm{Pt}^{\mathrm{II}}$ complexes, to induce GQ folding from the singlestranded sequence (TAGGG) ${ }_{2}$ in a buffer containing $\mathrm{K}^{+}$was investigated [76]. The authors demonstrated, using CD and UV-Vis experiments, that only $\mathrm{Zn}^{\mathrm{II}} \mathrm{TMPyP}$ was able to induce the folding of GQ structure of the studied sequence. A stoichiometry of 2:1 ( $\mathrm{Zn}^{\mathrm{II}} \mathrm{TMPyP}-$ [(TAGGG $\left.)_{2}\right]_{2}$ GQ) by end-stacking with an affinity constant $\left(K_{\mathrm{a}}\right)$ of about $10^{6} \mathrm{M}^{-1}$ was also reported from UV-Vis and isothermal calorimetry (ITC) titrations. The order for the GQ stabilizing ability of the studied compounds was $\mathrm{Zn}^{\mathrm{II}} \mathrm{TMPyP} \sim \mathrm{H}_{2} \mathrm{TMPyP}>\mathrm{Cu}^{\mathrm{II}} \mathrm{TMPyP}>\mathrm{Pt}^{\mathrm{II}} \mathrm{TMPyP}$. $\mathrm{PH}$ II TMPyP was referred to as not owning GQ stabilizing properties.

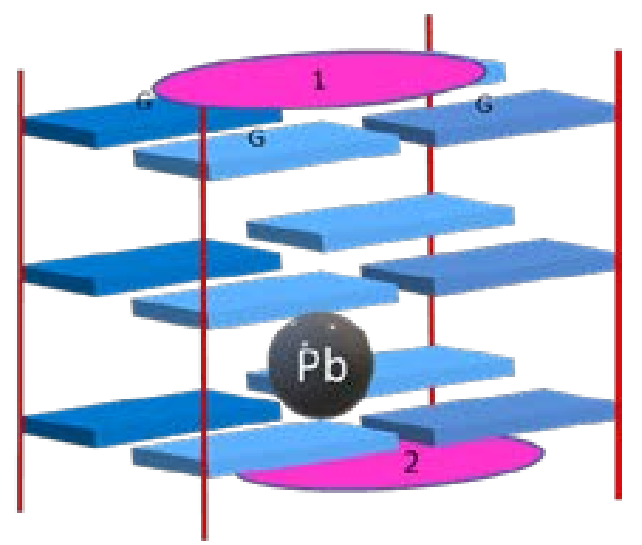

Figure 13. Pb-GQ structure with end-stacking of two $\mathrm{Zn}$ II TMPyP molecules (pink ellipses).

Later, the interaction of $\mathrm{Pt}^{\mathrm{II}} \mathrm{TMPyP}$ and $\mathrm{Pd}^{\mathrm{II}} \mathrm{TMPyP}$ complexes with quadruplex structures present in telomeres and oncogene promotors was again described in a study performed by Sabharwal et al. [77] using UV-Vis, fluorescence and CD spectroscopies, FRET melting assays and resonance light scattering. The obtained results suggest that both porphyrin complexes interact with telomeric quadruplex by $\pi-\pi$ stacking with a binding affinity of $10^{6}-10^{7} \mathrm{M}^{-1}$. A modest selectivity for quadruplex vs. duplex was described for both metalloporphyrins. Interesting results about the aggregation of $\mathrm{Pt}^{\mathrm{II}} \mathrm{TMPyP}$ under porphyrin excess conditions using Tel22 as a template were found. The authors noted the dissolution of the aggregates at concentration ratios $\left[\mathrm{Pt}^{\mathrm{II}} \mathrm{TMPyP}\right] /[\mathrm{Tel} 22] \leq 2$, reaching their maximum size at $\left[\mathrm{Pt}^{\mathrm{II}} \mathrm{TMPyP}\right] /[\mathrm{Tel} 22] \sim 8$.

The $\mathrm{Zn}^{\mathrm{II}} \mathrm{TMPyP}$ and $\mathrm{Cu}^{\mathrm{II}} \mathrm{TMPyP}$ complexes were revisited in a study where the interactions between the $\mathrm{H}_{2} \mathrm{TMPyP}\left(\right.$ or $\mathrm{H}_{2} \mathrm{TMPyP}_{4}$ ) and the isomeric structure $\mathrm{H}_{2} \mathrm{TMPyP} 2$ were evaluated with the tetramolecular sequences $T_{4} G_{4}$ and $T_{4} G_{4} T$ in the presence of buffer solutions containing $\mathrm{K}^{+}$or $\mathrm{Na}^{+}$ions [54]. Using CD, UV-Vis and fluorescence spectroscopy, the authors elucidate the effect of the $3^{\prime}-\mathrm{T}$ on the stabilization of porphyrins, binding modes, affinities and stoichiometries. This study provides information about the influence of metal center substitution and modulation of peripheral groups on porphyrin binding to GQ structures and identifies $\mathrm{Zn}^{\mathrm{II}} \mathrm{TMPyP}$ as a promising GQ ligand, its binding being once again proposed to occur by end-stacking.

The interaction of the $\mathrm{Zn}{ }^{\mathrm{II}} \mathrm{TMPyP}$ with three different GQ structures, $\left(\mathrm{TG}_{4} \mathrm{~T}_{4}\right)_{4}$, $\left(\mathrm{G}_{4} \mathrm{~T}_{4} \mathrm{G}_{4}\right)_{2}$ and $\mathrm{AG}_{3}\left(\mathrm{~T}_{2} \mathrm{AG}_{3}\right)_{3}$ with tetramolecular, bimolecular and unimolecular topologies, respectively, was also evaluated using transient absorption spectroscopy to monitor the triplet decay dynamics of $\mathrm{Zn}^{\mathrm{II}} \mathrm{TMPyP}$ [78]. The coexistence of different binding modes 
via $\pi-\pi$ stacking of porphyrin macrocycle and the G-quartets was quantitatively identified and described as being intercalation/end-stacking for $\left(G_{4} T_{4} G_{4}\right)_{2}$ and $A_{3}\left(T_{2} A G_{3}\right)_{3}$ and end-stacking/partial intercalation for $\left(\mathrm{TG}_{4} \mathrm{~T}_{4}\right)_{4}$. The authors reinforced that the intercalation process is undesirably affected by the steric hindrance of the axial water. Binding stoichiometric ratios of $1: 2$ for $\left(\mathrm{TG}_{4} \mathrm{~T}_{4}\right)_{4}$ and $\mathrm{AG}_{3}\left(\mathrm{~T}_{2} \mathrm{AG}_{3}\right)_{3}$, and of $1: 1$ for $\left(\mathrm{G}_{4} \mathrm{~T}_{4} \mathrm{G}_{4}\right)_{2}$, were reported for GQ/Zn ${ }^{\mathrm{II}} \mathrm{TMPyP}$ adducts.

The GQ stabilization ability and selectivity of the gold(III) porphyrin Au ${ }^{\mathrm{III}} \mathrm{TMPyP}$ was recently re-evaluated using biophysical and biochemical assay $[79,80]$ and compared with the behavior of other porphyrin derivatives (Figure 11A) already studied by Romera et al. [60]; porphyrins were also tested as inhibitors of telomerase. The authors showed an increase in the binding affinity of the porphyrin to the GQ target when a $\mathrm{Au}^{\mathrm{III}}$ ion was present in the porphyrin core. Modeling studies suggested that the insertion of the square planar $\mathrm{Au}^{\mathrm{III}}$ ion favors $\pi-\pi$ staking with stronger electrostatic interactions, since an extra positive charge is added to the porphyrin and a decrease in the electron density is induced.

An overview of the main obtained data with the cationic porphyrins selected in the studies reported here, like the DNA sequences used, binding mode, affinity, porphyrin:GQ stoichiometry, experimental conditions and the most relevant techniques, can be found below in Table 1. The structures of the porphyrins referred in Table 1 are resumed in Figure 14.

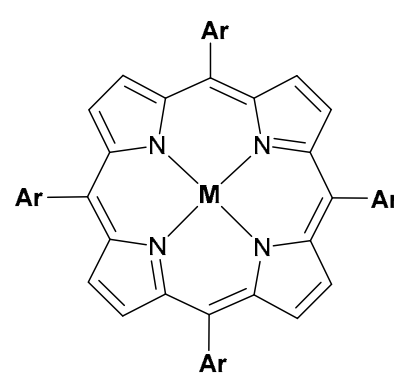

$M=2 H, C u^{\prime \prime}, \mathrm{Zn}^{\prime \prime}, \mathrm{Co}^{\prime \prime \prime}$, $\mathrm{Mn}^{\prime \prime \prime}, \mathrm{Ni}{ }^{\prime \prime}, \mathrm{Au}^{\text {III }}, \mathrm{Pd}^{\prime \prime}$ or Pt"

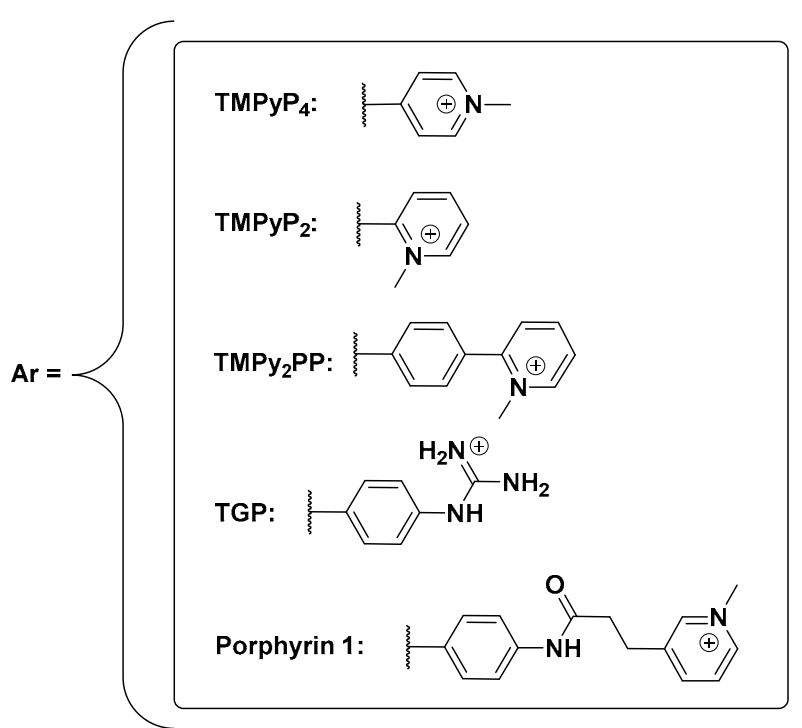

Figure 14. Structures of the porphyrins referred in Table 1.

The analysis of a high number of scientific articles comprising the interaction of $\mathrm{H}_{2} \mathrm{TMPyP}$, its metal complexes and some analogues with different DNA sequences by recurring to different methodologies and experimental conditions motivated us to complement this review with a screening where the behavior of $\mathrm{H}_{2} \mathrm{TMPyP}$ and of its $\mathrm{Zn}^{\mathrm{II}}, \mathrm{Co}{ }^{\mathrm{III}}$, $\mathrm{Ni}^{\mathrm{II}}, \mathrm{Cu}^{\mathrm{II}}, \mathrm{Pd}^{\mathrm{II}}$ and $\mathrm{Mn}^{\mathrm{III}}$ complexes as interactive GQ ligands was evaluated under the same experimental conditions and using the same GQ sequences. It is important to highlight that this evaluation allows comparing different complexes under unified conditions, facilitating the clear identification of the most promising compound. Taking advantage of the spectroscopic features of the porphyrins and metalloporphyrins, the possible impact of the experimental conditions on the interaction mode of these ligands was evaluated using readily accessible techniques such as UV-Vis and fluorescence spectroscopy. The screening was extended for the first time to the AgII complex of $\mathrm{H}_{2} \mathrm{TMPyP}$, and the selectivity of the ligands for GQ vs. duplex DNA structures was evaluated by performing the studies also in the presence of Salmon Sperm DNA. 


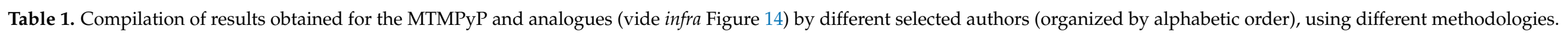

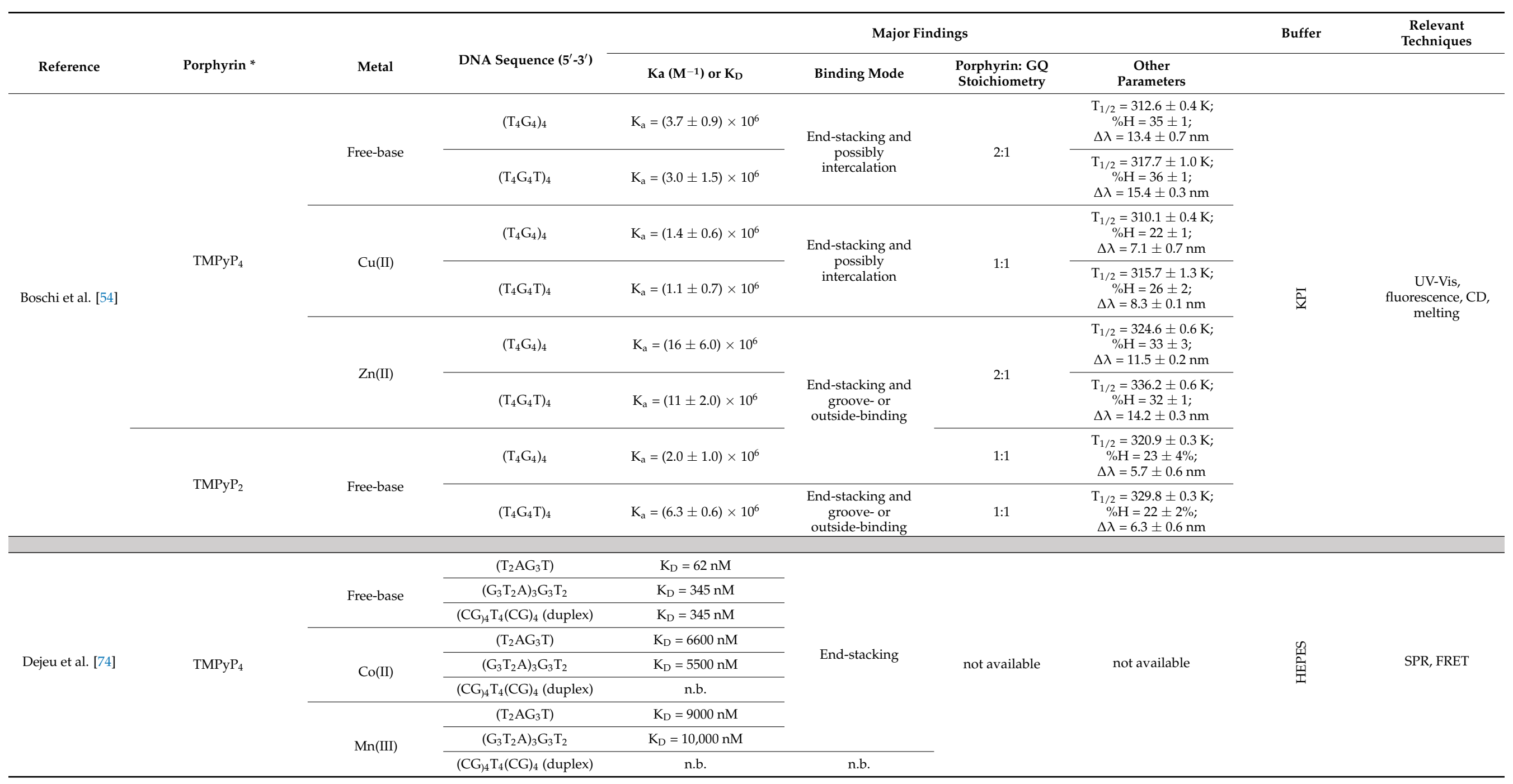


Table 1. Cont.

\begin{tabular}{|c|c|c|c|c|c|c|c|c|c|}
\hline \multirow[b]{2}{*}{ Reference } & \multirow[b]{2}{*}{ Porphyrin * } & \multirow[b]{2}{*}{ Metal } & \multirow{2}{*}{$\begin{array}{c}\text { DNA Sequence } \\
\left(5^{\prime}-3^{\prime}\right)\end{array}$} & \multicolumn{4}{|c|}{ Major Findings } & \multirow[t]{2}{*}{ Buffer } & \multirow[t]{2}{*}{$\begin{array}{c}\text { Relevant } \\
\text { Technique }\end{array}$} \\
\hline & & & & $\mathrm{Ka}\left(\mathbf{M}^{-1}\right)$ or $K_{D}$ & Binding Mode & $\begin{array}{c}\text { Porphyrin: GQ } \\
\text { Stoichiometry }\end{array}$ & $\begin{array}{c}\text { Other } \\
\text { Parameters }\end{array}$ & & \\
\hline \multirow{18}{*}{$\begin{array}{c}\text { Dejeu et al. } \\
\text { [74] }\end{array}$} & \multirow{2}{*}{$\mathrm{TMPyP}_{4}$} & \multirow{2}{*}{$\mathrm{Ni}(\mathrm{II})$} & $\left(\mathrm{G}_{3} \mathrm{~T}_{2} \mathrm{~A}\right)_{3} \mathrm{G}_{3} \mathrm{~T}_{2}$ & $\mathrm{~K}_{\mathrm{D}}=240 \mathrm{nM}$ & \multirow{8}{*}{ End-stacking } & \multirow{18}{*}{ not available } & & & \\
\hline & & & $\begin{array}{c}\left(\mathrm{CG}_{4} \mathrm{~T}_{4}(\mathrm{CG})_{4}\right. \\
\quad \text { (duplex) }\end{array}$ & $K_{D}=200 \mathrm{nM}$ & & & & & \\
\hline & \multirow{10}{*}{$\mathrm{TMPyP}_{2}$} & \multirow{2}{*}{ Free-base } & $\left(\mathrm{G}_{3} \mathrm{~T}_{2} \mathrm{~A}\right)_{3} \mathrm{G}_{3} \mathrm{~T}_{2}$ & $\mathrm{~K}_{\mathrm{D}}=114 \mathrm{nM}$ & & & & & \\
\hline & & & $\begin{array}{c}\left(\mathrm{CG}_{4} \mathrm{~T}_{4}(\mathrm{CG})_{4}\right. \\
\quad \text { (duplex) }\end{array}$ & $\mathrm{K}_{\mathrm{D}}=404 \mathrm{nM}$ & & & & & \\
\hline & & \multirow{3}{*}{$\mathrm{Co}(\mathrm{II})$} & $\left(\mathrm{T}_{2} \mathrm{AG}_{3} \mathrm{~T}\right)$ & $\mathrm{K}_{\mathrm{D}}=3.4 \mathrm{nM}$ & & & & & \\
\hline & & & $\left(\mathrm{G}_{3} \mathrm{~T}_{2} \mathrm{~A}\right)_{3} \mathrm{G}_{3} \mathrm{~T}_{2}$ & $\mathrm{~K}_{\mathrm{D}}=15 \mathrm{nM}$ & & & & & \\
\hline & & & $\begin{array}{c}\left(\mathrm{CG}_{4} \mathrm{~T}_{4}(\mathrm{CG})_{4}\right. \\
\text { (duplex) }\end{array}$ & $\mathrm{K}_{\mathrm{D}}=417 \mathrm{nM}$ & & & & & \\
\hline & & \multirow{2}{*}{$\mathrm{Mn}(\mathrm{III})$} & $\left(\mathrm{T}_{2} \mathrm{AG}_{3} \mathrm{~T}\right)$ & $\mathrm{K}_{\mathrm{D}}=4 \mathrm{nM}$ & & & \multirow{11}{*}{ not available } & & \\
\hline & & & $\begin{array}{c}\left(\mathrm{CG}_{4} \mathrm{~T}_{4}(\mathrm{CG})_{4}\right. \\
\quad \text { (duplex) }\end{array}$ & n.b. & n.b. & & & & \\
\hline & & \multirow{3}{*}{$\mathrm{Ni}(\mathrm{II})$} & $\left(\mathrm{T}_{2} \mathrm{AG}_{3} \mathrm{~T}\right)$ & $\mathrm{K}_{\mathrm{D}}=29 \mathrm{nM}$ & \multirow{8}{*}{ End-stacking } & & & & \\
\hline & & & $\left(\mathrm{G}_{3} \mathrm{~T}_{2} \mathrm{~A}\right)_{3} \mathrm{G}_{3} \mathrm{~T}_{2}$ & $\mathrm{~K}_{\mathrm{D}}=5.4 \mathrm{nM}$ & & & & & \\
\hline & & & $\begin{array}{c}\left(\mathrm{CG}_{4} \mathrm{~T}_{4}(\mathrm{CG})_{4}\right. \\
\text { (duplex) }\end{array}$ & $\mathrm{K}_{\mathrm{D}}=185 \mathrm{nM}$ & & & & & \\
\hline & \multirow{6}{*}{ TGP } & \multirow{3}{*}{ Free-base } & $\left(\mathrm{T}_{2} \mathrm{AG}_{3} \mathrm{~T}\right)$ & $K_{D}=83 n M$ & & & & & \\
\hline & & & $\left(G_{3} T_{2} A\right)_{3} G_{3} T_{2}$ & $\mathrm{~K}_{\mathrm{D}}=290 \mathrm{nM}$ & & & & & \\
\hline & & & $\begin{array}{l}\left(\mathrm{CG}_{4} \mathrm{~T}_{4}(\mathrm{CG})_{4}\right. \\
\quad \text { (duplex) }\end{array}$ & $K_{D}=16,000 \mathrm{nM}$ & & & & & \\
\hline & & \multirow{3}{*}{ Mn(III) } & $\left(\mathrm{T}_{2} \mathrm{AG}_{3} \mathrm{~T}\right)$ & $\mathrm{K}_{\mathrm{D}}=20 \mathrm{nM}$ & & & & & \\
\hline & & & $\left(\mathrm{G}_{3} \mathrm{~T}_{2} \mathrm{~A}\right)_{3} \mathrm{G}_{3} \mathrm{~T}_{2}$ & $\mathrm{~K}_{\mathrm{D}}=24 \mathrm{nM}$ & & & & & \\
\hline & & & $\begin{array}{c}\left(\mathrm{CG}_{4} \mathrm{~T}_{4}(\mathrm{CG})_{4}\right. \\
\quad \text { (duplex) }\end{array}$ & n.b. & n.b. & & & & \\
\hline
\end{tabular}


Table 1. Cont.

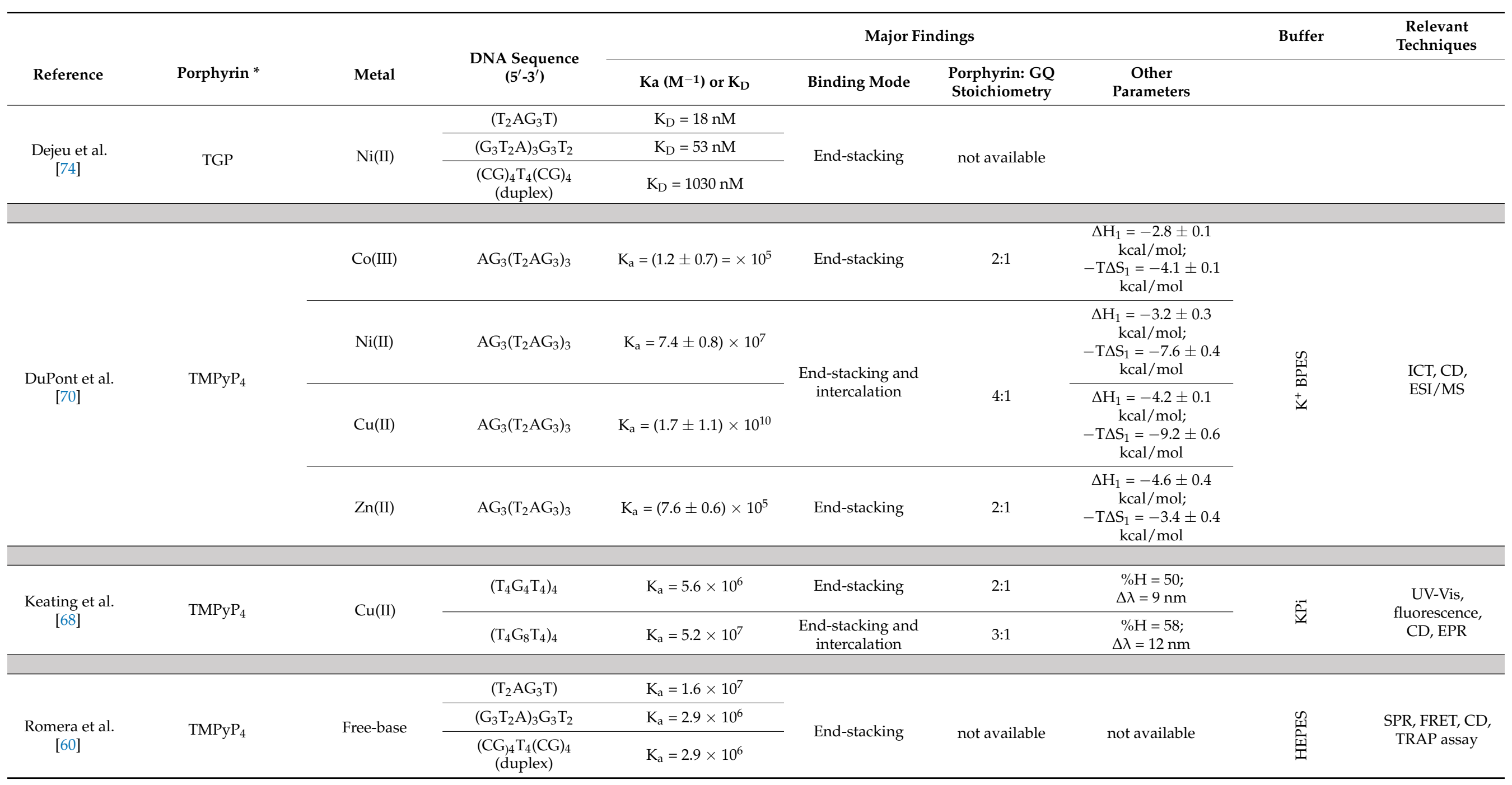


Table 1. Cont.

\begin{tabular}{|c|c|c|c|c|c|c|c|c|c|}
\hline \multirow[b]{2}{*}{ Reference } & \multirow[b]{2}{*}{ Porphyrin * } & \multirow[b]{2}{*}{ Metal } & \multirow{2}{*}{$\begin{array}{l}\text { DNA Sequence } \\
\qquad\left(5^{\prime}-3^{\prime}\right)\end{array}$} & \multicolumn{4}{|c|}{ Major Findings } & \multirow[t]{2}{*}{ Buffer } & \multirow[t]{2}{*}{$\begin{array}{c}\text { Relevant } \\
\text { Techniques }\end{array}$} \\
\hline & & & & $\mathrm{Ka}\left(\mathbf{M}^{-1}\right)$ or $\mathrm{K}_{\mathrm{D}}$ & Binding Mode & $\begin{array}{c}\text { Porphyrin: GQ } \\
\text { Stoichiometry }\end{array}$ & $\begin{array}{c}\text { Other } \\
\text { Parameters }\end{array}$ & & \\
\hline \multirow{12}{*}{$\begin{array}{c}\text { Romera et al. } \\
{[60]}\end{array}$} & \multirow{10}{*}{$\mathrm{TMPyP}_{4}$} & \multirow{3}{*}{$\mathrm{Au}(\mathrm{III})$} & $\left(\mathrm{T}_{2} \mathrm{AG}_{3} \mathrm{~T}\right)$ & $\mathrm{K}_{\mathrm{a}}=2.2 \times 10^{6}$ & & & & & \\
\hline & & & $\left(\mathrm{G}_{3} \mathrm{~T}_{2} \mathrm{~A}\right)_{3} \mathrm{G}_{3} \mathrm{~T}_{2}$ & $\mathrm{~K}_{\mathrm{a}}=1.2 \times 10^{6}$ & & & & & \\
\hline & & & $\begin{array}{c}(\mathrm{CG})_{4} \mathrm{~T}_{4}(\mathrm{CG})_{4} \\
\quad \text { (duplex) }\end{array}$ & $\mathrm{K}_{\mathrm{a}}=4.3 \times 10^{6}$ & & & & & \\
\hline & & \multirow{2}{*}{$\mathrm{Co}(\mathrm{III})$} & $\left(\mathrm{T}_{2} \mathrm{AG}_{3} \mathrm{~T}\right)$ & $\mathrm{K}_{\mathrm{a}}=1.5 \times 10^{5}$ & \multirow{2}{*}{ End-stacking } & \multirow{2}{*}{ not available } & \multirow{2}{*}{ not available } & & \\
\hline & & & $\left(\mathrm{G}_{3} \mathrm{~T}_{2} \mathrm{~A}\right)_{3} \mathrm{G}_{3} \mathrm{~T}_{2}$ & $\mathrm{~K}_{\mathrm{a}}=1.8 \times 10^{5}$ & & & & & \\
\hline & & \multirow{2}{*}{$\mathrm{Mn}(\mathrm{III})$} & $\left(\mathrm{T}_{2} \mathrm{AG}_{3} \mathrm{~T}\right)$ & $\mathrm{K}_{\mathrm{a}}=1.1 \times 10^{5}$ & \multirow{6}{*}{ End-stacking } & \multirow{7}{*}{ not available } & \multirow{7}{*}{ not available } & \multirow{7}{*}{$\begin{array}{l}0 \\
\text { 重 } \\
\text { 至 }\end{array}$} & \\
\hline & & & $\left(\mathrm{G}_{3} \mathrm{~T}_{2} \mathrm{~A}\right)_{3} \mathrm{G}_{3} \mathrm{~T}_{2}$ & $\mathrm{~K}_{\mathrm{a}}=1.0 \times 10^{5}$ & & & & & \\
\hline & & \multirow{3}{*}{$\mathrm{Ni}(\mathrm{II})$} & $\left(\mathrm{T}_{2} \mathrm{AG}_{3} \mathrm{~T}\right)$ & $\mathrm{K}_{\mathrm{a}}=1.7 \times 10^{7}$ & & & & & \\
\hline & & & $\left(\mathrm{G}_{3} \mathrm{~T}_{2} \mathrm{~A}\right)_{3} \mathrm{G}_{3} \mathrm{~T}_{2}$ & $\mathrm{~K}_{\mathrm{a}}=4.2 \times 10^{6}$ & & & & & \\
\hline & & & $\begin{array}{c}\left(\mathrm{CG}_{4} \mathrm{~T}_{4}(\mathrm{CG})_{4}\right. \\
\text { (duplex) }\end{array}$ & $\mathrm{K}_{\mathrm{a}}=5.0 \times 10^{6}$ & & & & & \\
\hline & \multirow[t]{2}{*}{ Porphyrin 1} & \multirow[t]{2}{*}{$\mathrm{Mn}(\mathrm{II})$} & $\left(\mathrm{G}_{3} \mathrm{~T}_{2} \mathrm{~A}\right)_{3} \mathrm{G}_{3} \mathrm{~T}_{2}$ & $\mathrm{~K}_{\mathrm{a}}=1.8 \times 10^{7}$ & & & & & \\
\hline & & & $\begin{array}{c}\left(\mathrm{CG}_{4} \mathrm{~T}_{4}(\mathrm{CG})_{4}\right. \\
(\text { duplex })\end{array}$ & n.b. & n.b. & & & & \\
\hline \multirow{3}{*}{$\begin{array}{c}\text { Sabater et al. } \\
\text { [73] }\end{array}$} & \multirow{3}{*}{ MA } & \multirow{3}{*}{$\mathrm{Co}(\mathrm{III})$} & $\left(\mathrm{T}_{2} \mathrm{AG}_{3} \mathrm{~T}\right)$ & $\mathrm{K}_{\mathrm{D}}=(17 \pm 0.4) \mathrm{nM}$ & \multirow{3}{*}{ End-stacking } & \multirow{3}{*}{ not available } & \multirow{3}{*}{ not available } & \multirow{3}{*}{ 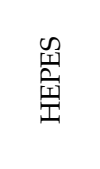 } & \multirow{3}{*}{$\begin{array}{l}\text { FRET melting } \\
\text { assay, SPR, CD } \\
\text { NMR }\end{array}$} \\
\hline & & & $\left(\mathrm{G}_{3} \mathrm{~T}_{2} \mathrm{~A}\right)_{3} \mathrm{G}_{3} \mathrm{~T}_{2}$ & $\mathrm{~K}_{\mathrm{D}}=(60.2 \pm 1.9) \mathrm{nM}$ & & & & & \\
\hline & & & $\begin{array}{c}\left(\mathrm{CG}_{4} \mathrm{~T}_{4}(\mathrm{CG})_{4}\right. \\
\text { (duplex) }\end{array}$ & $K_{D}=(3660 \pm 13.4) n M$ & & & & & \\
\hline
\end{tabular}


Table 1. Cont.

\begin{tabular}{|c|c|c|c|c|c|c|c|c|c|}
\hline \multirow[b]{2}{*}{ Reference } & \multirow[b]{2}{*}{ Porphyrin * } & \multirow[b]{2}{*}{ Metal } & \multirow{2}{*}{$\begin{array}{l}\text { DNA Sequence } \\
\qquad\left(5^{\prime}-3^{\prime}\right)\end{array}$} & \multicolumn{4}{|c|}{ Major Findings } & \multirow[t]{2}{*}{ Buffer } & \multirow[t]{2}{*}{$\begin{array}{c}\text { Relevant } \\
\text { Techniques }\end{array}$} \\
\hline & & & & $\mathrm{Ka}\left(\mathbf{M}^{-1}\right)$ or $\mathrm{K}_{\mathrm{D}}$ & Binding Mode & $\begin{array}{c}\text { Porphyrin: GQ } \\
\text { Stoichiometry }\end{array}$ & $\begin{array}{c}\text { Other } \\
\text { Parameters }\end{array}$ & & \\
\hline $\begin{array}{l}\text { Sabharwal } \\
\text { et al. [77] }\end{array}$ & $\mathrm{TMPyP}_{4}$ & $\mathrm{Pt}(\mathrm{II})$ & $\mathrm{AG}_{3}\left(\mathrm{~T}_{2} \mathrm{AG}_{3}\right)_{3}$ & $K_{a}=(5.8 \pm 0.8) \times 10^{6}$ & End-stacking & $7: 1$ & $\Delta \mathrm{T}=30.7 \pm 06^{\circ} \mathrm{C}$ & $\ddot{\underline{E}}$ & $\begin{array}{c}\text { UV-Vis, } \\
\text { fluorescence and } \\
\text { CD } \\
\text { spectroscopies, } \\
\text { FRET melting } \\
\text { assays, and } \\
\text { resonance light } \\
\text { scattering }\end{array}$ \\
\hline
\end{tabular}

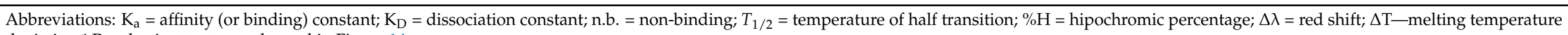
deviation * Porphyrin structures showed in Figure 14. 
3. Evaluation of the Interactions $\mathrm{H}_{2}$ TMPyP and of Its Metal Complexes $\left(\mathrm{M}=\mathrm{Ag}^{\mathrm{II}}\right.$, $\mathrm{Zn}^{\mathrm{II}}, \mathrm{Co}^{\mathrm{III}}, \mathrm{Ni}^{\mathrm{II}}, \mathrm{Pd}^{\mathrm{II}}, \mathrm{Mn}^{\mathrm{III}}$ and $\mathrm{Cu}^{\mathrm{II}}$ ) with $\mathrm{GQ}$ and ds DNA Structures

3.1. UV-Vis Spectroscopy

The free-base $\mathrm{H}_{2}$ TMPyP and the corresponding $\mathrm{Zn}^{\mathrm{II}}, \mathrm{Ni}^{\mathrm{II}}, \mathrm{Cu}^{\mathrm{II}}, \mathrm{Ag}^{\mathrm{II}}, \mathrm{Pd}^{\mathrm{II}}, \mathrm{Mn}^{\mathrm{III}}$ and $\mathrm{Co}^{\mathrm{III}}$ metallo complexes were prepared according to literature procedures $[25,81]$. In the selection of the complexes, we had into account several studies reporting that the $\mathrm{Zn}^{\mathrm{II}}$ and $\mathrm{Cu}^{\mathrm{II}}$ complexes are the better GQ stabilizers and telomerase inhibitors. The controversy concerning the influence of the axial water in the interaction of the $\mathrm{Mn}^{\mathrm{III}}$ or $\mathrm{Co}^{\mathrm{III}}$ porphyrin complexes prompted us also to evaluate the behavior of these complexes. The $\mathrm{Ag}^{\mathrm{II}}$ complex of TMPyP was considered since, to the best of our knowledge, this is the first time that this complex was evaluated as a GQ stabilizer.

The studies were undertaken using three different DNA sequences which give rise to different GQ topologies (Table 2 and Figure 15), namely the tetramolecular sequence $\left(\mathrm{TG}_{4} \mathrm{~T}\right)_{4}$, the bimolecular Oxytricha repeat oligonucleotide $\left(\mathrm{G}_{4} \mathrm{~T}_{4} \mathrm{G}_{4}\right)_{2}$ [82] and the human telomeric repeat $\left(\mathrm{AG}_{3}\left(\mathrm{~T}_{2} \mathrm{AG}_{3}\right)_{3}\right)$ [83]. A long-chain DNA strand (salmon sperm) was also used to compare the affinity and to evaluate the selectivity of the tested porphyrins for G-Quadruplex structures.

The oligonucleotide $\left(\mathrm{TG}_{4} \mathrm{~T}_{4}\right)_{4}$ assumes a parallel tetramolecular topology with guanine residues with glycosidic torsion angles in anti geometry, forming a right-handed helical structure with four equivalent grooves. This GQ is a Tetrahymena telomeric repeat sequence that results from the arrangement of four separate strands, thus not including any loop.

The oligonucleotide $\left(\mathrm{G}_{4} \mathrm{~T}_{4} \mathrm{G}_{4}\right)_{2}$ presents four stacked G-quartets and two groups of four thymine residues involved in the formation of two diagonals loops, thus acquiring a symmetrical antiparallel bimolecular GQ topology. Adjacent strands are alternately in parallel and antiparallel orientations, the guanine residues being consecutively in syn and anti geometries, in agreement with the syn-syn-anti-anti of the glycosidic torsion angles around each G-quartet. The same topology in the presence of $\mathrm{K}^{+}$and $\mathrm{Na}^{+}$ions was found in NMR solution studies [82].

Table 2. Sequence and topology of studied oligonucleotides.

\begin{tabular}{ccc}
\hline Oligonucleotide Sequence & Topology & Abbreviation \\
\hline $\begin{array}{c}5^{\prime} \text {-TGGGGT-3' } \\
\text { (Tetrahymena telomeric repeat) }\end{array}$ & Tetramolecular G-Quadruplex & $(\mathrm{TG} 4 \mathrm{~T})_{4}$ \\
\hline $\begin{array}{c}5^{\prime} \text {-GGG GTT TT GGG G-3' } \\
\text { (Oxytricha repeat oligonucleotide) }\end{array}$ & Bimolecular G-Quadruplex & $\left(\mathrm{G}_{4} \mathrm{~T}_{4} \mathrm{G}_{4}\right)_{2}$ \\
\hline $\begin{array}{c}5^{\prime} \text {-AGG GTT AGG GTTAGG GTT AGGG-3' } \\
\text { (human telomeric repeat) }\end{array}$ & Unimolecular G-Quadruplex & $\mathrm{AG}_{3}\left(\mathrm{~T}_{2} \mathrm{AG}_{3}\right)_{3}$ \\
\hline long single strand & Double-strand DNA & Salmon-sperm DNA \\
\hline
\end{tabular}

The human telomeric sequence $\mathrm{AG}_{3}\left(\mathrm{~T}_{2} \mathrm{AG}_{3}\right)_{3}$ could adopt distinct topologies in $\mathrm{K}^{+}$buffer solutions, which are different from the ones reported in the presence of $\mathrm{Na}^{+}$ cation [83]. The crystal structure of the $\mathrm{K}^{+}$form reveals that all GGG segments are in parallel positions with guanine residues in the anti geometry [84]. TTA loops connect the top and the bottom of two GGG strands and are in a double chain reversal conformation. The loop residues are positioned next to the grooves rather than at the quadruplex ends. The presence of these reversal loops limits the access to the grooves and so, the external quartets expose their planar surface areas that become available to aromatic ligands binding. The human telomeric sequence is also described as a mixture of antiparallel and hybrid structures [15]. Structure and topology of the three studied GQ are represented in Figure 15. In the case of the unimolecular GQ, the most common topologies are presented.

The typical electronic absorption spectra of porphyrins with a highly intense Soret band ranging from 413 to $461 \mathrm{~nm}$ accompanied by less intense $\mathrm{Q}$ bands (four for the free- 
bases and two for metalloporphyrins) between 500 and $650 \mathrm{~nm}$, prompted us to use UV-Vis to obtain qualitative and quantitative information about GQ/porphyrin interactions [41,42].

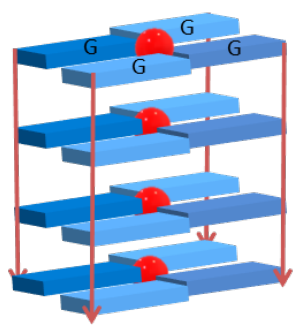

Tetramolecular $\left(\mathrm{TG}_{4} \mathrm{~T}\right)_{4}$

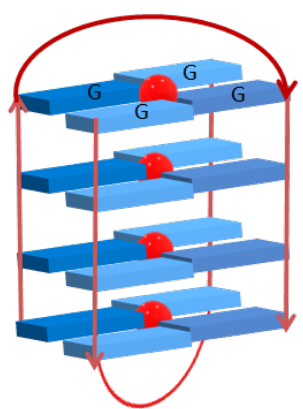

Bimolecular $\left(\mathbf{G}_{4} \mathbf{T}_{4} \mathbf{G}_{4}\right)_{2}$

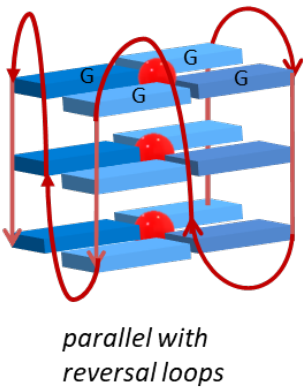

reversal loops

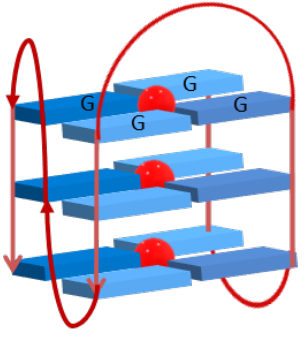

Hybrid - 1 structure

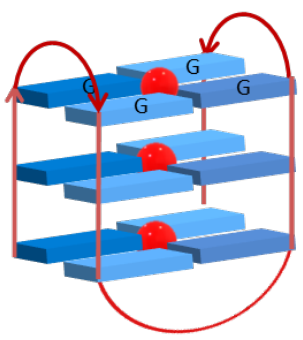

Hybrid - 2 structure

\section{Unimolecular $\mathrm{AG}_{3}\left(\mathrm{~T}_{2} \mathrm{AG}_{3}\right)_{3}$}

Figure 15. Structure and possible topology of the studied G-quadruplexes.

Under this context, when a ligand interacts with DNA structures, changes in its characteristic absorbance bands, such as hypochromic/hyperchromic and bathochromic (typically red shift) alterations, can occur depending on the type of interactions. The bathochromic shift is associated with a decrease in the $\pi-\pi^{*}$ transition energy due to the coupling of the $\pi$ bonding orbital of the DNA base pairs with the empty $\pi^{*}$ antibonding orbital of the ligand [32].

As a result of an intercalative binding process, typical values of hypochromicity higher than $35 \%$ and bathochromicity (red shift) above $15 \mathrm{~nm}$ in the Soret band are expected; it is important to take into account that these values were determined for long pieces of duplex DNA where the end-stacking is not significant $[32,67,85]$. Due to the less direct contact between $\pi$-systems, changes in the UV-Vis absorption spectra are less remarkable for groove binding or outside binding, for which red shifts lesser than $8 \mathrm{~nm}$ have been described [86,87]. Thus, by analyzing the batho- and hypochromic effects on the obtained spectra at the end of the titrations, it is possible to evaluate the affinity, the selectivity and to predict the type of interaction.

The UV-Vis titrations of the silver complex $\mathrm{Ag}^{\mathrm{II}} \mathrm{TMPyP}$, the free-base $\mathrm{H}_{2} \mathrm{TMPyP}$ and of the other MTMPyP complexes $\left(\mathrm{M}=\mathrm{Zn}^{\mathrm{II}}, \mathrm{Co}^{\mathrm{III}}, \mathrm{Ni}^{\mathrm{II}}, \mathrm{Pd}^{\mathrm{II}}, \mathrm{Mn}^{\mathrm{III}}\right.$ and $\left.\mathrm{Cu}^{\mathrm{II}}\right)$ were performed by adding aliquots of the selected GQ topologies, referred above in Table 2, and of the doublestranded DNA structure in phosphate buffer saline (PBS) to each ligand; the titrations were stopped after obtaining a constant absorbance during three successive additions of each oligonucleotide (see details of the experimental procedures and of the structure, molar extinction coefficient $(\varepsilon)$ and absorbance maximum $\left(\lambda_{\max }\right)$ of all the studied porphyrins in Supplementary Materials as Table S1). Blank experiments were performed with PBS buffer before the titration of each ligand with the selected DNA structures (data not shown).

The UV-Vis spectra obtained with $\mathrm{H}_{2}$ TMPyP and with the metal complexes MTMPyP, where $\mathrm{M}=\mathrm{Ag}^{\mathrm{II}}, \mathrm{Zn}^{\mathrm{II}}, \mathrm{Co}^{\mathrm{III}}, \mathrm{Ni}^{\mathrm{II}}, \mathrm{Pd}^{\mathrm{II}}, \mathrm{Cu}^{\mathrm{II}}$ and $\mathrm{Mn}^{\mathrm{III}}$, at the end of the titrations with each 
GQ structures are summarized in the Supplementary Materials, Figure S6. The results of red shifts, hypochromism percentage, stoichiometry (L:DNA) and $\mathrm{K}_{\mathrm{b}}$ values obtained for $\mathrm{H}_{2} \mathrm{TMPyP}$ and for the metal complexes in the presence of each DNA structure are summarized in Table 3.

As an example, the changes observed in the UV-Vis spectra of AgII TMPyP during its titration with the different $G Q$ structures $A_{3}\left(T_{2} A_{G}\right)_{3}$ (unimolecular), $G_{4} T_{4} G_{4}$ (bimolecular) and $\mathrm{TG}_{4} \mathrm{~T}$ (tetramolecular) and with the salmon sperm double-stranded DNA are presented in Figure 16 (see also Figures S1-S5, in Supplementary Materials).

From the data obtained it is possible to observe that the $\mathrm{AgII}$ derivative presents high affinity and selectivity for all the GQ structures, since red shifts between 9 and $13 \mathrm{~nm}$ and binding constants $\left(\mathrm{K}_{\mathrm{b}}\right)$ in the range of $1.63 \times 10^{6}-1.13 \times 10^{7}$ (Table 3, entry 1 ) were found. In the case of double-stranded (ds) salmon sperm, a red shift of $7 \mathrm{~nm}$ and a Kb of $6.97 \times 10^{4}$ was observed.

The observed red shifts and hypochromism percentages between $18 \%$ and $22 \%$, observed in the titrations with GQ, are consistent with an external interaction, probably by end-stacking $[86,87]$. The high difference observed between the unimolecular $G Q$, $\mathrm{AG}_{3}\left(\mathrm{~T}_{2} \mathrm{AG}_{3}\right)_{3},\left(\mathrm{~K}_{\mathrm{b}}=1.13 \times 10^{7}\right)$ and the ds DNA $\left(\mathrm{K}_{\mathrm{b}}=6.97 \times 10^{4}\right)$ structures is highly indicative of the selectivity of the AgII TMPyP ligand towards GQ structures. The binding constant observed for AgII TMPyP is 10-fold higher than the one observed for the free-base $\mathrm{H}_{2} \mathrm{TMPyP}$ (Table 3, entry 2) and it is the highest value obtained for the metalloporphyrins (Table 3, entries 3-7). These results, along with the observed selective behavior, indicate that AgIITMPyP can be a promising GQ stabilizing ligand. The 3:1 ligand-to-GQ (L:GQ) stoichiometry obtained for the tetra and bimolecular topologies and 4:1 L:GQ for the unimolecular one reinforces the ability of this ligand to interact with GQ structures.

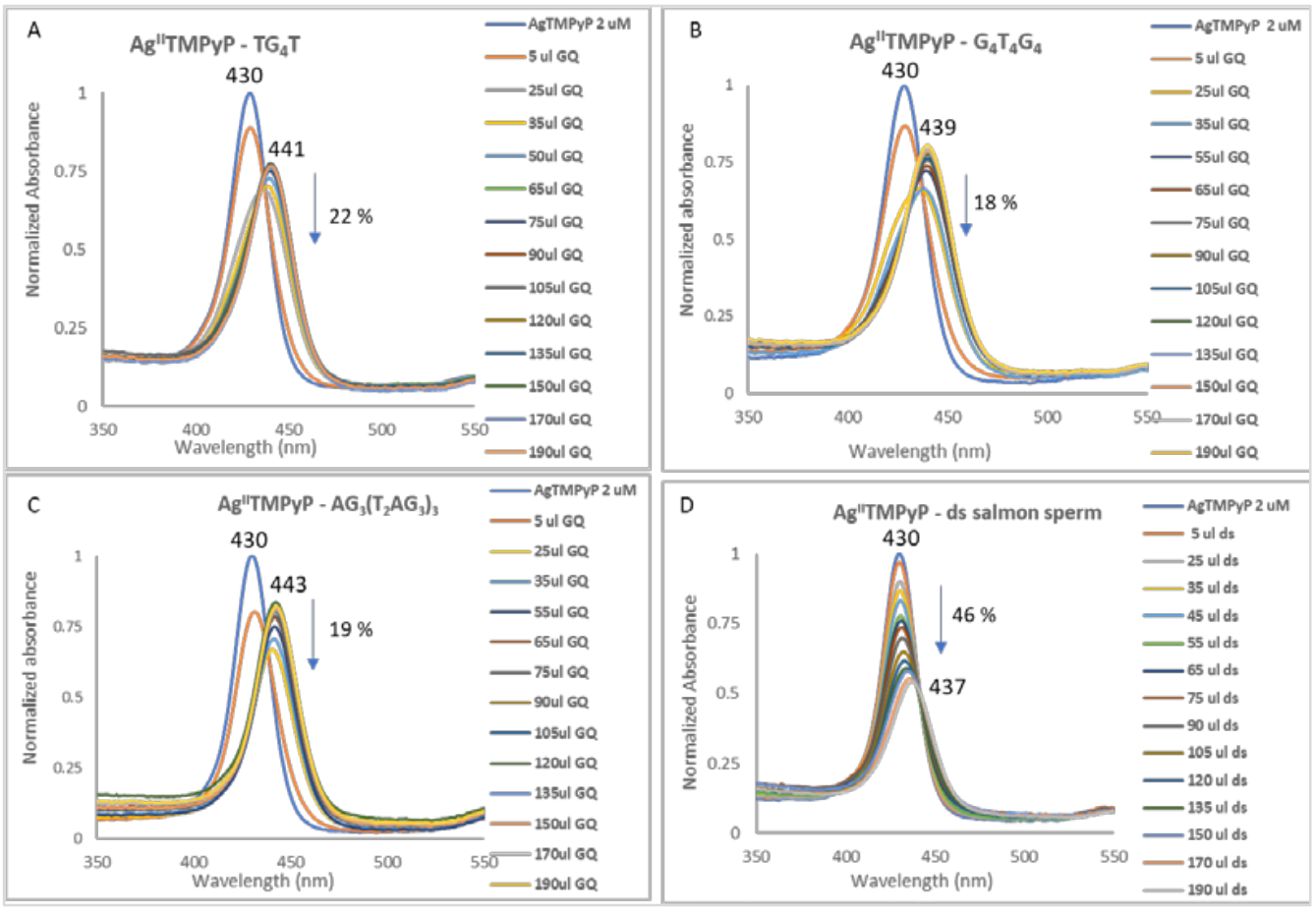

Figure 16. UV-Vis spectra (350-650 nm) obtained for Ag ${ }^{\mathrm{II}} \mathrm{TMPyP}$ and (A) tetramolecular GQ, (B) bimolecular GQ, (C) unimolecular GQ and (D) salmon sperm double-stranded DNA. DNA structures were prepared in $20 \mathrm{mM}$ PBS buffer with $100 \mathrm{mM} \mathrm{KCl}$. 
Table 3. Red shift, \% hypochromism and $\mathrm{Kb}$ values obtained for $\mathrm{H}_{2} \mathrm{TMPyP}$ and its metal complexes.

\begin{tabular}{|c|c|c|c|c|c|c|}
\hline \multirow[b]{2}{*}{ Entry } & & \multirow[b]{2}{*}{$\left(\mathrm{TG}_{4} \mathrm{~T}\right)_{4}$} & \multicolumn{2}{|l|}{ G-Quadruplexes (GQ) } & \multicolumn{2}{|l|}{ Double-Stranded (ds) } \\
\hline & & & $\left(G_{4} T_{4} G_{4}\right)_{2}$ & $\begin{array}{c}\mathrm{AG}_{3} \\
\left(\mathrm{~T}_{2} \mathrm{AG}_{3}\right)_{3}\end{array}$ & Salmon Sperm & Ligand (L) \\
\hline \multirow{4}{*}{ (1) } & Red shift (nm) & 11 & 9 & 13 & 7 & \multirow{4}{*}{$\mathrm{Ag}^{\mathrm{II}} \mathrm{TMPyP}$} \\
\hline & \% Hypochromism & 22 & 18 & 19 & 46 & \\
\hline & L:DNA Stoichiometry & $3: 1$ & $3: 1$ & $4: 1$ & n.a. & \\
\hline & $\mathrm{K}_{\mathrm{b}}\left(\mathrm{M}^{-1}\right)$ & $(1.63 \pm 0.31) \times 10^{6}$ & $(6.72 \pm 0.41) \times 10^{6}$ & $(1.13 \pm 0.41) \times 10^{7}$ & $(6.97 \pm 0.37) \times 10^{4}$ & \\
\hline \multirow{4}{*}{ (2) } & Red shift (nm) & 11 & 3 & 16 & 12 & \multirow{4}{*}{$\mathrm{H}_{2} \mathrm{TMPyP}$} \\
\hline & \% Hypochromism & 23 & 41 & 28 & 36 & \\
\hline & L:DNA Stoichiometry & $3: 1$ & $3: 2$ & $4: 1$ & $1: 1$ & \\
\hline & $\mathrm{K}_{\mathrm{b}}\left(\mathrm{M}^{-1}\right)$ & $(1.66 \pm 0.41) \times 10^{6}$ & $(6.43 \pm 0.44) \times 10^{5}$ & $(2.57 \pm 0.47) \times 10^{6}$ & $(1.49 \pm 0.32) \times 10^{6}$ & \\
\hline \multirow{4}{*}{ (3) } & Red shift (nm) & 13 & 8 & 14 & 2 & \multirow{4}{*}{$\mathrm{Zn}^{\mathrm{II}} \mathrm{TMPyP}$} \\
\hline & \% Hypochromism & 17 & 74.6 & 27 & 5 & \\
\hline & L:DNA Stoichiometry & $3: 1$ & $3: 1$ & $4: 1$ & $2: 1$ & \\
\hline & $\mathrm{K}_{\mathrm{b}}\left(\mathrm{M}^{-1}\right)$ & $(3.25 \pm 0.38) \times 10^{6}$ & $(8.57 \pm 0.76) \times 10^{5}$ & $(4.33 \pm 0.43) \times 10^{6}$ & $(3.52 \pm 0.74) \times 10^{5}$ & \\
\hline \multirow{4}{*}{ (4) } & Red shift (nm) & 0 & -3 & 12 & 1 & \multirow{4}{*}{$\mathrm{Co}^{\mathrm{III}} \mathrm{TMPyP}$} \\
\hline & \% Hypochromism & 26 & 23 & 32 & 49 & \\
\hline & L:DNA Stoichiometry & $3: 1$ & $3: 1$ & $4: 1$ & $1: 1$ & \\
\hline & $\mathrm{K}_{\mathrm{b}}\left(\mathrm{M}^{-1}\right)$ & $(5.30 \pm 0.89) \times 10^{5}$ & $(1.86 \pm 0.58) \times 10^{5}$ & $(1.00 \pm 0.39) \times 10^{6}$ & $(1.36 \pm 0.40) \times 10^{5}$ & \\
\hline \multirow{4}{*}{ (5) } & Red shift (nm) & 8 & 6 & 12 & 6 & \multirow{4}{*}{$\mathrm{Ni}^{\mathrm{II}} \mathrm{TMPyP}$} \\
\hline & \% Hypochromism & 40 & 42 & 35 & 24 & \\
\hline & L:DNA Stoichiometry & $3: 1$ & $3: 1$ & $3: 1$ & $1: 1$ & \\
\hline & $\mathrm{K}_{\mathrm{b}}\left(\mathrm{M}^{-1}\right)$ & $(8.28 \pm 0.39) \times 10^{6}$ & $(2.56 \pm 0.41) \times 10^{6}$ & $(4.84 \pm 0.44) \times 10^{6}$ & $(1.11 \pm 0.39) \times 10^{6}$ & \\
\hline \multirow{4}{*}{ (6) } & Red shift (nm) & 9 & 8 & 14 & 8 & \multirow{4}{*}{$\mathrm{Pd}^{\mathrm{II}}$ TMPyP } \\
\hline & \% Hypochromism & 5 & 12 & 14 & 24 & \\
\hline & L:DNA Stoichiometry & $4: 1$ & $3: 1$ & $4: 1$ & $2: 1$ & \\
\hline & $\mathrm{K}_{\mathrm{b}}\left(\mathrm{M}^{-1}\right)$ & $(6.55 \pm 0.38) \times 10^{6}$ & $(1.35 \pm 0.41) \times 10^{6}$ & $(9.26 \pm 0.36) \times 10^{6}$ & $(2.64 \pm 0.44) \times 10^{6}$ & \\
\hline \multirow{4}{*}{ (7) } & Red shift (nm) & 6 & 1 & 8 & 1 & \multirow{4}{*}{$\mathrm{Cu}^{\mathrm{II}} \mathrm{TMPyP}$} \\
\hline & \% Hypochromism & 28 & 15 & 28 & 3 & \\
\hline & L:DNA Stoichiometry & $4: 1$ & $3: 1$ & $3: 1$ & $1: 1$ & \\
\hline & $\mathrm{K}_{\mathrm{b}}\left(\mathrm{M}^{-1}\right)$ & $(3.67 \pm 0.42) \times 10^{6}$ & $(2.49 \pm 0.41) \times 10^{5}$ & $(2.33 \pm 0.44) \times 10^{6}$ & $(5.58 \pm 0.79) \times 10^{5}$ & \\
\hline
\end{tabular}

The differences (lower red shift and hypochromic effect) observed between the bimolecular and the GQ in tetra and unimolecular conformations can be justified by the presence of two diagonal loops in the bimolecular conformations (Figure 15) that can difficult the ligand binding to the GQ structure in special if end-stacking is considered.

For the $\mathrm{Mn}^{\mathrm{III}}$ complex, the interaction with both the GQ tetramolecular and the doublestranded salmon sperm was almost absent (Figure $\mathrm{S6H}$; this lack of interaction was not introduced in Table 3). These results confirm the previous reports, [60,71,72] pointing to the poor stabilization and stacking interactions by $\mathrm{Mn}^{\mathrm{III}}$ complexes due to the presence of water molecules as axial ligands; no more studies were performed with this complex.

Overall, from the data obtained it is possible to observe that, with exception of the $\mathrm{Mn}^{\mathrm{III}}$ complex, the free-base $\mathrm{H}_{2} \mathrm{TMPyP}$ and the metalloporphyrins present good affinity for both DNA structures. Higher affinity for the GQ structures, when compared to the observed for double-stranded DNA, was observed when considering the unimolecular conformation $\mathrm{AG}_{3}\left(\mathrm{~T}_{2} \mathrm{AG}_{3}\right)_{3}$, for which the $\mathrm{K}_{\mathrm{b}}$ are in the range of $10^{6}-10^{7} \mathrm{M}^{-1}$.

For $\mathrm{Co}^{\mathrm{III}} \mathrm{TMPyP}$ (Table 3, entry 4 and Figure S6D) the most significant bathochromic effect was observed for the unimolecular GQ (with a red-shift of $12 \mathrm{~nm}$ ) while the bimolecular GQ structure showed a blue shift of $3 \mathrm{~nm}$; the insignificant or absent bathochromic effect observed in the spectra of the tetramolecular conformation $(\Delta \lambda=0 \mathrm{~nm})$ and of the salmon sperm $(\Delta \lambda=1 \mathrm{~nm})$ can be associated with the presence of water molecules as axial ligands confirming their negative influence in the macrocycle interaction with DNA structures, as previously reported [71,72].

For the $\mathrm{Ni}^{\mathrm{II}} \mathrm{TMPyP}$ derivative (Table 3 , entry 5), a $\mathrm{K}_{\mathrm{b}}$ with $10^{6} \mathrm{M}^{-1}$ order was found for the GQ and double-stranded structures, pointing to the low selectivity of this derivative for GQ structures. This low selectivity for GQ structures was also observed for the widely 
studied $\mathrm{H}_{2}$ TMPyP. In general, when compared with the free base, the $\mathrm{Ni}^{\mathrm{II}}$ derivative showed higher $\mathrm{K}_{\mathrm{b}}$ values.

The Pd ${ }^{\mathrm{II}} \mathrm{TMPyP}$ (Table 3, entry 6) complex showed high affinity for the GQ structures, especially for the unimolecular topology, and a pattern of selectivity was also identified, especially when comparing unimolecular GQ and the double-stranded structure.

Similar behavior was observed for the $\mathrm{Cu}^{\mathrm{II}} \mathrm{TMPyP}$ (Table 3, entry 7) ligand, although the obtained data points this complex to having lower affinity for DNA structures, which is consistent with their lower binding constants when compared to the data here reported for the other studied complexes, except for Co ${ }^{\mathrm{III}} \mathrm{TMPyP}$ (Figure 17).

Red shifts lower than $15 \mathrm{~nm}$ and hypochromic percentages, in general, lower than $35 \%$ were observed for all the studied complexes, except for the $\mathrm{Ni}^{\mathrm{II}}$ complex that showed hypochromic percentages around $40 \%$, pointing to the occurrence of interaction by external stacking of ligands in the GQ structure. The type of interaction of the free-base $\mathrm{H}_{2} \mathrm{TMPyP}$ has been involved in controversy in the scientific community, with some authors pointing to intercalation as the binding mode, while a higher number of authors point to interaction as occurring via external binding $[31,60,88]$.

It is interesting to note that, with exception of the Ag ${ }^{\mathrm{II}} \mathrm{TMPyP}$ derivative, when looking to the obtained $\mathrm{K}_{\mathrm{b}}$ values, the interaction of the MTMPyP derivatives with the studied bimolecular $G Q,\left(G_{4} T_{4} G_{4}\right)_{2}$, is again weaker. As mentioned before, this fact could be related to the presence, in the GQ structure, of two diagonal loops that can limit the access of the ligands to the terminal tetrads. The high affinity of the Ag ${ }^{\mathrm{II}} \mathrm{TMPyP}$ for the bimolecular GQ is evidence of the high affinity of this derivative for GQ structures.

For better visualization of the impact of the ligands in each GQ and double-stranded DNA, the $\mathrm{K}_{\mathrm{b}}$ observed at the end of the UV-Vis titration of the MTMPyP ligands and the selected DNA sequences are compared in Figure 17A,B.

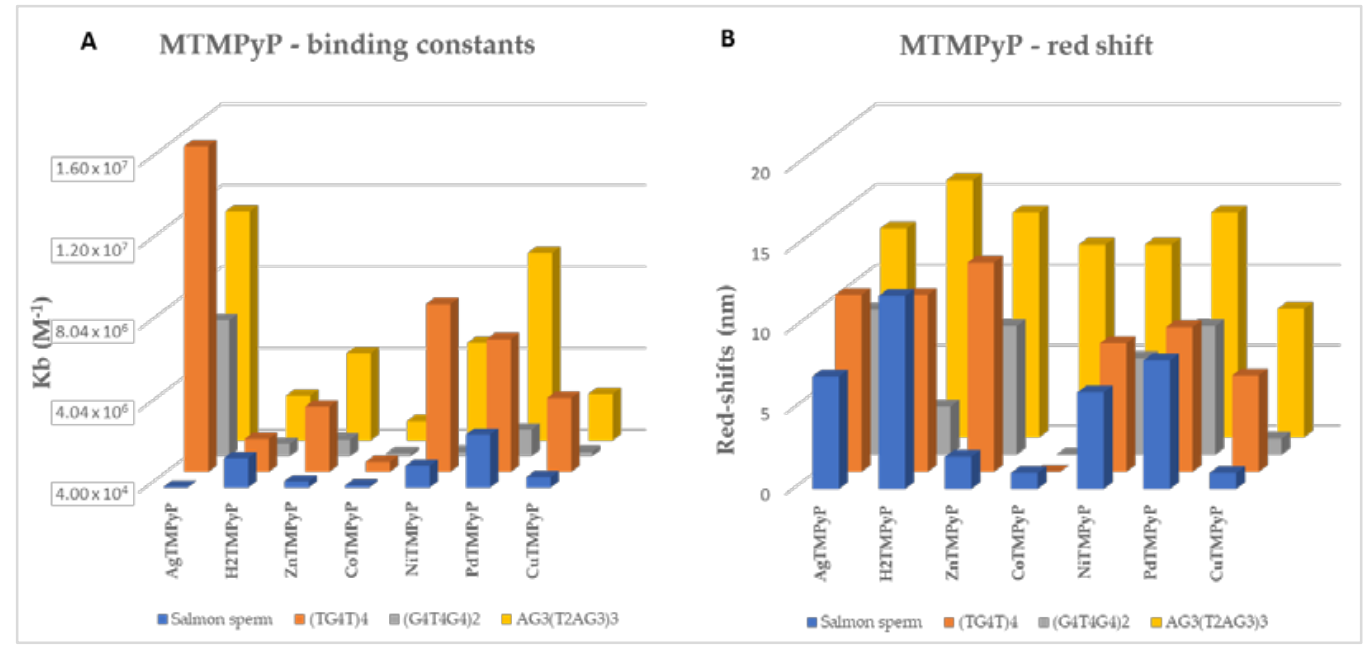

Figure 17. (A) binding constants $\left(\mathrm{K}_{\mathrm{b}}\right)\left(\mathrm{M}^{-1}\right)$ and $(\mathbf{B})$ red shift observed at the end of the UV-Vis titration of the MTMPyP ligands and the selected DNA sequences.

When analyzing the obtained binding constants, $\mathrm{K}_{\mathrm{b}}$ values in the range of $2.5 \times 10^{5}-1.6 \times 10^{7} \mathrm{M}^{-1}$ were obtained in general for the GQ structures, pointing to high affinity for these structures; for the studied double-stranded DNA, $\mathrm{K}_{\mathrm{b}}$ values in the range of $6.7 \times 10^{4}-2.6 \times 10^{6} \mathrm{M}^{-1}$ were found, representing slight interactions and confirming ligands selectivity for GQ structures. The results obtained for the AgIITMPyP complex are very important since they point to this ligand as a promising ligand for selective GQ stabilization, since the obtained $\mathrm{K}_{\mathrm{b}}$ values are higher for GQ and much lower (21- or 5-fold) for the ds DNA than those obtained for the $\mathrm{H}_{2} \mathrm{TMPyP}$ or the $\mathrm{Zn}^{\mathrm{II}} \mathrm{TMPyP}$ derivatives, both described as promising GQ stabilizing agents.

In general, the obtained results (Table 3) are in good agreement with the previous ones reported in literature (Table 1). The order of magnitude found for the $K_{b}$ of free-base 
$\mathrm{H}_{2} \mathrm{TMPyP}$ with the tetramolecular structure $\left(\mathrm{TG}_{4} \mathrm{~T}\right)_{4}$ is in accordance with the one reported by Boschi et al. for a similar tetramolecular GQ sequence $\left(10^{6} \mathrm{M}^{-1}\right)$. In addition, the observed hypochromism and red-shift values are close to the reported values.

Our results suggest that the introduction of $\mathrm{Zn}$ (II) increased the binding affinity of the free-base porphyrin to all tested GQ sequences, just as observed by Boschi et al. Still, the experimental $\mathrm{K}_{\mathrm{b}}$ found for the unimolecular GQ $\mathrm{AG}_{3}\left(\mathrm{~T}_{2} \mathrm{AG}_{3}\right)_{3}\left(4.33 \times 10^{6} \mathrm{M}^{-1}\right)$ was higher than the one reported by DuPont et al. $\left(7.6 \times 10^{5} \mathrm{M}^{-1}\right)$ using different techniques. The $\mathrm{K}_{\mathrm{b}}$ found for $\mathrm{Co}^{\mathrm{III}} \mathrm{TMPyP}$ with $\mathrm{AG}_{3}\left(\mathrm{~T}_{2} \mathrm{AG}_{3}\right)_{3}\left(1.00 \times 10^{6} \mathrm{M}^{-1}\right)$ was one order of magnitude superior to the one described by DuPont et al. $\left(1.2 \times 10^{5} \mathrm{M}^{-1}\right)$, while for $\mathrm{Ni}^{\mathrm{II}} \mathrm{TMPyP}$ it was one order of magnitude lower $\left(4.8 \times 10^{6}\right.$ vs. $7.4 \times 10^{7} \mathrm{M}^{-1}$, respectively). For Pd ${ }^{\mathrm{II}} \mathrm{TMPyP}$, a significant resemblance was observed between our experimental results $\left(9.3 \times 10^{6} \mathrm{M}^{-1}\right)$ and the value reported by Sabarwal et al., $\left(1.0 \times 10^{7} \mathrm{M}^{-1}\right)$, for the $\mathrm{AG}_{3}\left(\mathrm{~T}_{2} \mathrm{AG}_{3}\right)_{3}$. The $\mathrm{K}_{\mathrm{b}}$ value of $\mathrm{Cu}^{\mathrm{II}} \mathrm{TMPyP}$ with the unimolecular GQ $\left(2.3 \times 10^{6} \mathrm{M}^{-1}\right)$ is significantly inferior to the one described by DuPont et al., $\left(1.7 \times 10^{10} \mathrm{M}^{-1}\right)$. Nonetheless, the red shift and hypochormism values retrieved from the titrations with the tetramolecular GQ are in proximity to the ones reported by Boschi et al., for similar GQ sequences.

\subsection{Fluorescence Experiments}

The G-Quadruplex fluorescent intercalator displacement (G4-FID) assay is another well-established method to evaluate and confirm the affinity of a ligand for GQ and in particular its selectivity for GQ. This assay is based on the loss of fluorescence of a probe, the thiazole orange (TO), as a result of its displacement from DNA by a ligand $[41,42,45]$. The concentration of the ligands required to decrease the fluorescence of the probe (TO) by $50 \%$ is noted by $\mathrm{DC}_{50}$.

To validate the UV-Vis data obtained for the AgII complex, its ability to displace TO from the unimolecular $\mathrm{GQ}$ structure $\mathrm{AG}_{3}\left(\mathrm{~T}_{2} \mathrm{AG}_{3}\right)_{3}$ and from the double-stranded salmon sperm was evaluated by fluorescence spectroscopy (Figure 18).

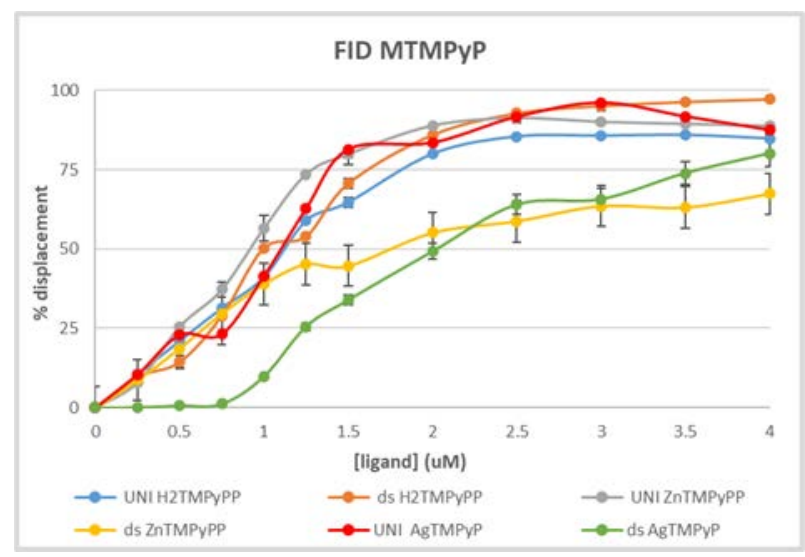

Figure 18. G4-FID assay performed for the in PBS at $25^{\circ} \mathrm{C}$ with the $\mathrm{Ag}^{\mathrm{II}} \mathrm{TMPyP}$ using the unimolecular GQ $\left(\mathrm{AG}_{3}\left(\mathrm{~T}_{2} \mathrm{AG}_{3}\right)_{3}\right)$ and double-stranded salmon sperm. A comparison with the results obtained with the $\mathrm{H}_{2} \mathrm{TMPyP}$ and the $\mathrm{Zn}{ }^{\mathrm{II}} \mathrm{TMPyP}$ is presented.

As can be seen, the results obtained for the Ag ${ }^{\mathrm{II}} \mathrm{TMPyP}$, red line for the displacement of TO from the GQ structure $\left(\mathrm{DC}_{50}=0.99 \mathrm{uM}\right)$ and green line for the displacement of $\mathrm{TO}$ from the double-stranded structure $\left(\mathrm{DC}_{50}=2.03 \mathrm{uM}\right)$, point to a pattern of selectivity already highlighted by the UV-Vis data. For comparison, the results with the $\mathrm{H}_{2} \mathrm{TMPyP}$ and the $\mathrm{Zn}{ }^{\mathrm{II}} \mathrm{TMPyP}$ are also present, confirming the lack of selectivity of the free-base porphyrin. Similar behavior of selectivity was observed for both the $\mathrm{Zn}^{\mathrm{II}}$ and the $\mathrm{Ag}{ }^{\mathrm{II}}$ metal complexes. 


\section{Conclusions}

Overall, the reported data show that the free-base $\mathrm{H}_{2} \mathrm{TMPyP}$, analogues and metalloporphyrin counterparts present good affinity for the GQ DNA structures, with the exceptions of the $\mathrm{Mn}^{\mathrm{III}}$ and $\mathrm{Co}^{\mathrm{III}}$ complexes, for which axial ligands are present. In general, the authors reinforced that the intercalation process is undesirably affected by the steric hindrance of the axial water in metal complexes, the external stacking being pointed as the most probable binding mode.

The binding mode of porphyrins and metalloporphyrins occurs mainly by $\pi-\pi$ stacking, specifically end-stacking on the top of the G-quartets at the termini of the quadruplex structures. An enhanced binding affinity was proposed for metalloporphyrins through an additional electrostatic interaction induced by the presence of metal ions. It has been found that the nature of the metal influences not only the kinetics but also the ligand binding mode.

Complexes containing square planar $\left(\mathrm{Cu}^{\mathrm{II}}\right)$ and pyramidal $\left(\mathrm{Zn}^{\mathrm{II}}\right)$ geometries revealed to be the better inhibitors and their geometry was correlated with the unhindered face for stacking offered by porphyrins owning these metal centers. In the case of the $\mathrm{Cu}^{\mathrm{II}} \mathrm{TMPyP}$ complex, a binding stoichiometric ratio of 2:1 ( $\left.\mathrm{Cu}^{\mathrm{II}} \mathrm{TMPyP}-\mathrm{GQ}\right)$ was described, and endstacking of $\mathrm{Cu}^{\mathrm{II}} \mathrm{TMPyP}$ in both G-quadruplex ends was proposed.

In the case of the $\mathrm{Mn}^{\mathrm{III}}$ porphyrin derivatives, slow kinetics were described. Perturbation of the coordination sphere of the metal ion upon interaction with DNA or a binding mode that is different from stacking (external binding) were pointed to explain this behavior. The presence of water molecules on its porphyrin core was indicated as a factor that prevents the porphyrin intercalation between the base pairs of DNA and, consequently, decreases the porphyrins binding affinity to double-stranded DNA. On the other hand, the authors recognize that axial water molecules might hinder the initial stacking of the porphyrin molecule on the G-quadruplex end, thus justifying their lower stabilization properties. Similar behavior was described in the case of the Co ${ }^{\mathrm{III}}$ complex.

The order for the GQ stabilizing ability was $\mathrm{Zn}{ }^{\mathrm{II}} \mathrm{TMPyP} \sim \mathrm{H}_{2} \mathrm{TMPyP}>\mathrm{Cu}{ }^{\mathrm{II}} \mathrm{TMPyP}>$ $\mathrm{Pt}^{\mathrm{II}}$ TMPyP. Pt ${ }^{\mathrm{II}}$ TMPyP was referred to as not owning GQ stabilizing properties. Modeling studies suggested that the insertion of the square planar $\mathrm{Au}^{\mathrm{III}}$ ion favors $\pi-\pi$ staking with stronger electrostatic interactions derived from the presence of an extra positive charge in the porphyrin core that induces a decrease in the electron density and an increase in the binding affinity of the porphyrin to the GQ target.

The collected data in the spectroscopic screening, performed under unified conditions, suggests that the free-base $\mathrm{H}_{2} \mathrm{TMPyP}$ and the metalloporphyrins present good affinity for both DNA structures, with the exceptions of the $\mathrm{Mn}^{\mathrm{III}}$ and $\mathrm{Co}^{\mathrm{III}}$ complexes. In particular, higher affinity constants for the GQ structures, when compared to those observed for double-stranded DNA, were obtained, especially for the unimolecular conformation $\mathrm{AG}_{3}\left(\mathrm{~T}_{2} \mathrm{AG}_{3}\right)_{3}$, for which the $\mathrm{K}_{\mathrm{b}}$ values are in the range of $10^{6}-10^{7} \mathrm{M}^{-1}$. In the case of the $\mathrm{Mn}^{\mathrm{III}}$ and $\mathrm{CO}^{\mathrm{III}}$ complexes, the lower stabilization properties, probably resulting from the presence of water molecules as axial ligands, already observed by other authors, were confirmed.

The new derivative AgII TMPyP showed good affinity for GQ-DNA structures, with binding constants in the range of $10^{6}-10^{7} \mathrm{M}^{-1}$ and ligand-GQ stoichiometric ratios of 3:1 and $4: 1$.

The process of discovering ligands with high affinity and selectivity for GQ is challenging and could open new horizons on the anticancer therapies based on the detection and stabilization of G-quadruplexes. Considering the affinity of the AgII complex for GQ structures and a predictable pattern of selectivity, demonstrated out by the UV-Vis and fluorescence screening presented herein, further studies must be performed to confirm and complement the obtained data.

Supplementary Materials: The following are available online at https:/ / www.mdpi.com/article/ 10.3390/biom11101404/s1, Table S1: Structures of the studied porphyrins, relevant photophysical 
parameters, Figure S1: UV-Vis spectra obtained from titration of $\mathrm{Ag}^{\mathrm{II}} \mathrm{TMPyP}$ with the tetramolecular GQ DNA structure $\mathrm{TG}_{4} \mathrm{~T}$, Figure S2: UV-Vis spectra obtained from titration of $\mathrm{Ag}^{\mathrm{II}} \mathrm{TMPyP}$ with the bimolecular GQ DNA structure $\mathrm{G}_{4} \mathrm{~T}_{4} \mathrm{G}_{4}$, Figure S3: UV-Vis spectra obtained from titration of AgIITMPyP with the unimolecular GQ DNA structure $\mathrm{AG}_{3}\left(\mathrm{~T}_{2} \mathrm{AG}_{3}\right)_{3}$, Figure S4: UV-Vis spectra obtained from titration of AgIITMPyP with the double-stranded DNA structures from salmon sperm, Figure S5: Mass spectrum of the $\mathrm{Ag}^{\mathrm{II}} \mathrm{TMPyP}$ derivative, Figure S6: Comparative UV-Vis absorption spectra (350-650 nm) at the end of titration (1:3 L:DNA) of the solution of (A) AgII TMPyP, (B) $\mathrm{H}_{2} \mathrm{TMPyP},(\mathrm{C}) \mathrm{Zn}^{\mathrm{II}} \mathrm{TMPyP},(\mathrm{D}) \mathrm{Co}^{\mathrm{III}} \mathrm{TMPyP}$ (E) Ni ${ }^{\mathrm{II}} \mathrm{TMPyP},(\mathrm{F}) \mathrm{Pd}^{\mathrm{II}} \mathrm{TMPyP},(\mathrm{G}) \mathrm{Cu}^{\mathrm{II}} \mathrm{TMPyP}$ and $(\mathrm{H}) \mathrm{Mn}{ }^{\mathrm{II}} \mathrm{TMPyP}(2.0 \mu \mathrm{M})$ with the selected unimolecular, bimolecular and tetramolecular GQ structures and salmon sperm double-stranded DNA.

Author Contributions: Conceptualization-C.I.V.R., N.M.M.M. and M.G.P.M.S.N.; writing-original draft preparation-C.I.V.R., A.R.M.; writing—review and editing-N.M.M.M., M.A.F.F., T.T. and M.G.P.M.S.N.; supervision-M.G.P.M.S.N. and C.I.V.R. All authors have read and agreed to the published version of the manuscript.

Funding: This research was funded by the University of Aveiro and the Fundação para a Ciência e a Tecnologia (FCT). Financial support was provided by LAQV-REQUIMTE (Ref.UIDB/50006/2020) and CICECO-Aveiro Institute of Materials (Ref. UID/CTM/50011/2020) through national funds and, where applicable, co-financed by the FEDER, within the PT2020 Partnership Agreement. The authors also acknowledge the Portuguese NMR and Mass Networks. Catarina IV Ramos (REF.-04788-ARH/2018) and Nuno MM Moura (REF.-048-88-ARH/2018) acknowledge their research contracts which are funded by national funds (OE), through FCT-Fundação para a Ciência e a Tecnologia, I.P., in the scope of the framework contract foreseen in numbers 4, 5 and 6 of the article 23, of the Law Decree 57/2016, of August 29, changed by Law 57/2017, of July 19. Ana R. Monteiro thanks FCT for her Ph.D. grant SFRH/BD/137356/2018.

Institutional Review Board Statement: Not applicable.

Informed Consent Statement: Not applicable.

Data Availability Statement: The experimental data presented in this study are available in Supplementary Material.

Conflicts of Interest: The authors declare no conflict of interest.

\section{References}

1. McClintock, B. The stability of broken ends of chromosomes in Zea mays. Genetics 1941, 26, 234. [CrossRef]

2. Nandakumar, J.; Cech, T.R. Finding the end: Recruitment of telomerase to the telomere. Nat. Rev. Mol. Cell Biol. $2013,14,69$. [CrossRef]

3. Blackburn, E.H. A history of telomere biology. In Telomeres, 2nd ed.; de Lange, T., Lundblad, V., Blackburn, E.H., Eds.; Cold Spring Harbor Laboratory Press: Cold Spring Harbor, NY, USA, 2006; pp. 1-19.

4. Shay, J.W.; Zou, Y.; Hiyama, E.; Wright, W.E. Telomerase and cancer. Hum. Mol. Genet. 2001, 10, 677. [CrossRef] [PubMed]

5. Chen, Y.; Zhang, Y. Functional and mechanistic analysis of telomerase: An antitumor drug target. Pharmacol. Ther. 2016, 163, 24. [CrossRef]

6. Kim, N.W.; Piatyszek, M.A.; Prowse, K.R.; Harley, C.B.; West, M.D.; Ho, P.L.C.; Coviello, G.M.; Wright, W.E.; Weinrich, S.L.; Shay, J.W. Specific Association of Human Telomerase Activity with Immortal Cells and Cancer. Science 1994, 266, $2011-2016$. [CrossRef]

7. Balasubramanian, S.; Hurley, L.H.; Neidle, S.; Targeting, G. quadruplexes in gene promoters: A novel anticancer strategy? Nat. Rev. Drug Discov. 2011, 10, 261. [CrossRef]

8. Mishra, S.; Kota, S.; Chaudhary, R.; Misra, H.S. Guanine quadruplexes and their roles in molecular processes. Crit. Rev. Biochem. Mol. Biol. 2021, 56, 482. [CrossRef]

9. Neidle, S. Quadruplex Nucleic Acids as Novel therapeutic targets. J. Med. Chem. 2016, 16, 5987. [CrossRef] [PubMed]

10. Collie, G.W.; Parkinson, G.N. The application of DNA and RNA G-quadruplexes to therapeutic medicines. Chem. Soc. Rev. 2011, 40, 5867. [CrossRef]

11. De Cian, A.; Lacroix, L.; Douarre, C.; Temime-Smaali, N.; Trentesaux, C.; Riou, J.-F.; Mergny, J.-L. Targeting Telomeres and Telomerase. Biochimie 2008, 90, 131. [CrossRef] [PubMed]

12. Yang, D.; Okamoto, K. Structural Insights into G-Quadruplexes: Towards New Anticancer Drugs. Future Med. Chem. 2010, 2, 619. [CrossRef]

13. Hadjiliadis, N.; Sletten, E. Metal Complex-DNA Interactions; Blackwell Publishing Ltd. Wiley: Chippenham, UK, 2009. 
14. Ma, Y.; Iida, K.; Nagasawa, K. Topologies of G-Quadruplexes: Biological Functions and Regulation by Ligands. Biochem. Biophys. Res. Commun. 2020, 531, 3. [CrossRef]

15. Adrian, M.; Heddi, B.; Phan, A. NMR Spectroscopy of G-Quadruplexes. Methods 2012, 57, 11. [CrossRef]

16. Largy, E.; Mergny, J.-L.; Gabelica, V. Role of Alkali Metal Ions in G-Quadruplex Nucleic Acid Structure and Stability. The Alkali Metal Ions: Their Role for Life; Springer: Berlin/Heidelberg, Germany, 2016; pp. 203-258.

17. Mohanty, D.; Bansa, M. Conformational Polymorphism in G-Tetraplex Structures: Strand Reversal by Base Flipover or Sugar Flipover. Nucleic Acids Res. 1993, 21, 1767. [CrossRef] [PubMed]

18. Huang, Z.-S.; Tan, J.-H.; Ou, T.-M.; Li, D.; Gu, L.-Q. G-Quadruplex DNA and its Ligands in Anticancer Therapy. In Medicinal Chemistry of Nucleic Acids; John Wiley \& Sons, Inc.: Hoboken, NJ, USA, 2011; Wiley Chap 5; pp. $206-257$.

19. Tanpure, A.A.; Srivatsan, S.G. Conformation-sensitive nucleoside analogues as topology-specific fluorescence turn-on probes for DNA and RNA G-quadruplexes. Nucleic Acids Res. 2015, 43, e149. [CrossRef]

20. Schrank, Z.; Khan, N.; Osude, C.; Singh, S.; Miller, R.J.; Merrick, C.; Mabel, A.; Kuckovic, A.; Puri, N. Oligonucleotides targeting telomeres and telomerase in cancer. Molecules 2018, 9, 2267. [CrossRef] [PubMed]

21. Yaku, H.; Murashima, T.; Miyoshi, D.; Sugimoto, N. Specific binding of anionic porphyrin and phthalocyanine to the G-quadruplex with a variety of in vitro and in vivo applications. Molecules 2012, 17, 10586. [CrossRef] [PubMed]

22. Bidzinska, J.; Cimino-Reale, G.; Zaffaroni, N.; Folini, M. G-quadruplex structures in the human genome as novel therapeutic targets. Molecules 2013, 18, 12368. [CrossRef]

23. Moye, A.L.; Porter, K.C.; Cohen, S.B.; Phan, T.; Zyner, K.G.; Sasaki, N.; Lovrecz, G.O.; Beck, J.L.; Bryan, T.M. Telomeric G-quadruplexes are a substrate and site of localization for human telomerase. Nat. Commun. 2015, 6, 7643. [CrossRef]

24. Hou, J.Q.; Chen, S.-B.; Zan, L.P.; Ou, T.M.; Tan, J.H.; Luyt, L.G.; Huang, Z.S. Identification of a selective G-quadruplex DNA binder using a multistep virtual screening approach. Chem. Commun. 2015, 51, 198. [CrossRef]

25. Cavaleiro, J.A.S.; Tomé, A.C.; Neves, M.G.P.M.S. Handbook of Porphyrin Science. In Meso-Tetraphenylporphyrin Derivatives: New Synthetic Methodologies; Smith, K.M.K., Kadish, K.M., Guilard, R., Eds.; World Scientific Publishing Company Co.: Singapore, 2010; Volume 2, pp. 193-294.

26. Moura, N.M.M.; Ramos, C.I.V.; Linhares, I.; Santos, S.M.; Faustino, M.A.F.; Almeida, A.; Cavaleiro, J.A.S.; Amado, F.M.L.; Lodeiro, C.; Neves, M.G.P.M.S. Synthesis, characterization and biological evaluation of cationic porphyrin-terpyridine derivatives. RSC Adv. 2016, 6, 110674. [CrossRef]

27. Ramos, C.I.V.; Figueira, F.; De Polêto, M.; Amado, F.M.L.; Verli, H.; Tomé, J.P.C.; Neves, M.G.P.M.S. ESI-MS/MS of Expanded Porphyrins: A Look into Their Structure and Aromaticity. J. Mass Spectrom. 2016, 51, 342. [CrossRef]

28. Ramos, C.I.V.; Moura, N.M.M.; Santos, S.M.F.; Faustino, M.A.F.; Tomé, J.P.C.; Amado, F.M.L.; Santana-Marques, M.G.; De Paula, R.; Simões, M.M.Q.; Neves, M.G.P.M.S. An insight into the gas-phase fragmentations of potential molecular sensors with porphyrinchalcone structures. Int. J. Mass Spectrom. 2015, 392, 164. [CrossRef]

29. Eddahmi, M.; Moura, N.M.M.; Ramos, C.I.V.; Bouissane, L.; Faustino, M.A.F.; Cavaleiro, J.A.S.; Rakib, M.; Neves, M.G.P.M.S. An insight into the vicarious nucleophilic substitution reaction of 2-nitro-5,10,15,20-tetraphenylporphyrin with p-chlorophenoxyacetonitrile: Synthesis and gas-phase fragmentation studies. Arab. J. Chem. 2020, 13, 5849. [CrossRef]

30. Monteiro, A.R.; Ramos, C.I.V.; Fateixa, S.; Moura, N.M.M.; Neves, M.G.P.M.S.; Trindade, T. Hybrids based on graphene oxide and porphyrin as a tool for detection and stabilization of DNA G-quadruplexes. ACS Omega 2018, 3, 11184. [CrossRef] [PubMed]

31. Ramos, C.I.V.; Santana-Marques, M.G.; Tomé, J.P.C. Charge and substituent effects on the stability of porphyrin/G-quadruplex adducts. J. Mass Spectrom. 2012, 47, 173. [CrossRef] [PubMed]

32. Ramos, C.I.V.; Almeida, S.P.; Lourenço, L.M.O.; Pereira, P.M.; Fernandes, R.; Faustino, M.A.F.; Tomé, J.P.C.; Carvalho, J.; Cruz, C.; Neves, M.G.P.M.S. Multicharged phthalocyanines as selective ligands for G-Quadruplex DNA structures. Molecules 2019, 24, 733. [CrossRef] [PubMed]

33. Lopes-Nunes, J.; Carvalho, J.; Figueiredo, J.; Ramos, C.I.V.; Lourenço, L.M.O.; Tomé, J.P.C.; Neves, M.G.P.M.S.; Mergny, J.-L.; Queiroz, J.A.; Salgado, G.F.; et al. Phthalocyanines for G-quadruplex aptamers binding. Bioorg. Chem. 2020, 100, 103920. [CrossRef]

34. Madureira, J.; Marques, M.; Maia, C.; Sousa, B.; Campino, L.; Santana-Marques, M.G.; Farrell, N. Nonclassic Metallointercalators with Dipyridophenazine: DNA Interaction Studies and Leishmanicidal Activity. Inorg. Chem. 2013, 52, 8881. [CrossRef]

35. Ramos, C.I.V.; Barros, C.M.; Fernandes, A.M.; Santana-Marques, M.G.; Correia, A.J.F.; Tomé, J.P.C.; Carrilho, M.D.C.T.; Faustino, M.A.F.; Tomé, A.C.; Neves, M.G.P.M.S.; et al. Interactions of cationic porphyrins with double-stranded oligodeoxynucleotides: A study by electrospray ionisation mass spectrometry. J. Mass Spectrom. 2005, 40, 1439. [CrossRef]

36. Ramos, C.I.V.; Santana-Marques, M.G. Electrospray mass spectrometry for the study of the non-covalent interactions of porphyrins and duplex desoxyribonucleotides. J. Porphyr. Phthalocyanines 2009, 13, 518. [CrossRef]

37. Silva, E.M.P.; Ramos, C.I.V.; Pereira, P.M.R.; Giuntini, F.; Faustino, M.A.F.; Tomé, J.P.C.; Tomé, A.C.; Silva, A.M.S.; Santana-Marques, M.G.; Neves, M.G.P.M.S.; et al. Cationic-vinyl substituted meso-tetraphenylporphyrins: Synthesis and non-covalent interactions with a short poly $(\mathrm{dGdC})$ duplex. J. Porphyr. Phthalocyanines 2012, 16, 101. [CrossRef]

38. Sun, D.; Thompson, B.; Cathers, B.E.; Salazar, M.; Kerwin, S.M.; Trent, J.O.; Jenkins, T.C.; Neidle, S.; Hurley, L.H. Inhibition of human telomerase by a G-quadruplex interactive compound. J. Med. Chem. 1997, 40, 2113. [CrossRef] [PubMed]

39. Ou, T.-M.; Lu, Y.-J.; Tan, J.; Huang, Z.; Wong, K.; Gu, L. G-Quadruplexes: Targets in anticancer drug design. ChemMedChem 2008, 3, 690. [CrossRef] [PubMed] 
40. Duarte, A.R.; Cadoni, E.; Ressurreição, A.S.; Moreira, R.; Paulo, A. Design of Modular G-quadruplex Ligands. ChemMedChem 2018, 13, 869. [CrossRef]

41. Jaumot, J.; Gargallo, R. Experimental Methods for Studying the Interactions between G-Quadruplex Structures and Ligands. Curr. Pharm Design. 2012, 18, 1900. [CrossRef]

42. Murat, P.; Singh, Y.; Defrancq, E. Methods for investigating G-quadruplex DNA / ligand interactions. Chem. Soc. Rev. 2011, 40, 5293. [CrossRef] [PubMed]

43. Sirajuddin, M.; Ali, S.; Badshah, A. Drug-DNA interactions and their study by UV-Visible, fluorescence spectroscopies and cyclic voltammetry. J. Photochem. Photobiol. B Biol. 2013, 124, 1-19. [CrossRef]

44. Carvalho, J.; Quintela, T.; Gueddouda, N.M.; Bourdoncle, A.; Mergny, J.-L.; Salgado, G.F.; Queiroz, J.A.; Cruz, C. Phenanthroline polyazamacrocycles as G-quadruplex DNA binders. Org. Biomol. Chem. 2018, 16, 2776. [CrossRef]

45. Largy, E.; Hamon, F.; Teulade-Fichou, M.-P. Development of a high-throughput G4-FID assay for screening and evaluation of small molecules binding quadruplex nucleic acid structures. Anal. Bioanal. Chem. 2011, 400, 3419. [CrossRef]

46. Marchand, A.; Strzelecka, D.; Gabelica, V. Selective and Cooperative Ligand Binding to Antiparallel Human Telomeric DNA G-Quadruplexes. Chem. Eur. J. 2016, 22, 9551. [CrossRef]

47. Casagrande, A.; Alvino, A.; Bianco, G.; Franceschin, O.M. Study of binding affinity and selectivity of perylene and coronene derivatives towards duplex and quadruplex DNA by ESI-MS. J. Mass Spectrom. 2009, 44, 530. [CrossRef]

48. Lecours, M.J.; Marchand, A.; Anwar, A.; Guetta, C.; Hopkins, W.S.; Gabelica, V. What stoichiometries determined by mass spectrometry reveal about the ligand binding mode to G-quadruplex nucleic acids. Biochim. Biophys. Acta 2017, $1861,1353$. [CrossRef]

49. Read, M.; Harrison, R.J.; Romagnoli, B.; Tanious, F.A.; Gowan, S.H.; Reszka, A.P.; Wilson, W.D.; Kelland, L.R.; Neidle, S. Structure-based design of selective and potent G-quadruplex-mediated telomerase inhibitors. Proc. Natl. Acad. Sci. USA 2001, 98, 4844. [CrossRef]

50. Fedoroff, O.Y.; Salazar, M.; Han, H.Y.; Chemeris, V.V.; Kerwin, S.M.; Hurley, L.H. NMR-based model of a telomerase-inhibiting compound bound to G-quadruplex DNA. Biochemistry 1998, 37, 12367. [CrossRef] [PubMed]

51. Mergny, J.L.; Lacroix, L.; Teulade-Fichou, M.P.; Hounsou, C.; Guittat, L.; Hoarau, M.; Arimondo, P.B.; Vigneron, J.P.; Lehn, J.M.; Riou, J.F.; et al. Telomerase inhibitors based on quadruplex ligands selected by a fluorescence assay. Proc. Natl. Acad. Sci. USA 2001, 98, 3062. [CrossRef] [PubMed]

52. Carvalho, J.; Mergny, J.-L.; Salgado, G.F.; Queiroz, J.A.; Cruz, C. G-quadruplex, Friend or Foe: The Role of the G-quartet in Anticancer Strategies. Trends Mol. Med. 2020, 26, 848. [CrossRef] [PubMed]

53. Wheelhouse, R.T.; Sun, D.K.; Han, H.Y.; Han, F.X.G.; Hurley, L.H. Cationic porphyrins as telomerase inhibitors: The interaction of tetra-(N-methyl-4-pyridyl)porphine with quadruplex DNA. J. Am. Chem. Soc. 1998, 120, 3261. [CrossRef]

54. Boschi, E.; Davis, S.; Taylor, S.; Butterworth, A.; Chirayath, L.A.; Purohit, V.; Siegel, L.K.; Buenaventura, J.; Sheriff, A.H.; Jin, R.; et al. Interaction of a Cationic Porphyrin and Its Metal derivatives with G-Quadruplex DNA. J. Phys. Chem. B 2016, 120, 12807. [CrossRef] [PubMed]

55. Zhang, L.-M.; Cui, Y.-X.; Zhu, L.-N.; Chu, J.-Q.; Kong, D.-M. Cationic porphyrins with large side arm substituents as resonance light scattering ratiometric probes for specific recognition of nucleic acid G-quadruplexes. Nucleic Acids Res. 2019, $47,2727$. [CrossRef]

56. Monchaud, D.; Teulade-Fichou, M.-P. A hitchhiker's guide to G-quadruplex ligands. Org. Biomol. Chem. 2008, 6, 627. [CrossRef] [PubMed]

57. Zhang, S.; Wu, Y.; Zhang, W. G-quadruplex structures and their interaction diversity with ligands. Chem. Med. Chem. 2014, 9, 899. [CrossRef] [PubMed]

58. Neidle, S.; Balasubramanian, S. Quadruplex Nucleic Acids; RSC Publishing: Cambridge, UK, 2006. [CrossRef]

59. Georgiades, S.N.; Karim, N.H.A.; Suntharalingam, K.; Vilar, R. Interaction of Metal Complexes with G-Quadruplex DNA. Angew. Chem. Int. Ed. 2010, 49, 4020. [CrossRef] [PubMed]

60. Romera, C.; Bombarde, O.; Bonnet, R.; Gomez, D.; Dumy, P.; Calsou, P.; Gwan, J.F.; Lin, J.H.; Defrancq, E.; Pratviel, G. Improvement of porphyrins for G-quadruplex DNA targeting. Biochimie 2011, 93, 1310. [CrossRef]

61. Milagrom, L.R. The Colours of Life; Oxford University Press: Oxford, UK, 1997.

62. Vallejo, M.C.S.; Reis, M.J.A.; Pereira, A.M.V.M.; Serra, V.V.; Cavaleiro, J.A.S.; Moura, N.M.M.; Neves, M.G.P.M.S. Merging pyridine(s) with porphyrins and analogues: An overview of synthetic approaches. Dye. Pigment. 2021, 191, 109298. [CrossRef]

63. Monchaud, D.; Granzhan, A.; Saettel, N.; Guédin, A.; Mergny, J.L.; Teulade-Fichou, M.P. One ring to bind them all-part I: The efficiency of the macrocyclic scaffold for g-quadruplex DNA recognition. J. Nucleic Acids 2010, 2010, 525862. [CrossRef]

64. Rowland, G.B.; Barnett, K.; DuPont, J.I.; Akurathi, G.; Le, V.H.; Lewis, E.A. The effect of pyridyl substituents on the thermodynamics of porphyrin binding to G-quadruplex DNA. Bioorg. Med. Chem. 2013, 21, 7515. [CrossRef]

65. Izbicka, E.; Wheelhouse, R.T.; Raymond, E.; Davidson, K.K.; Lawrence, R.A.; Sun, D.; Windle, B.E.; Hurley, L.H.; Von Hoff, D.D. Effects of Cationic Porphyrins as G-Quadruplex Interactive Agents in Human Tumor Cells. Cancer Res. 1999, 59, 639.

66. Vialas, C.; Pratviel, G.; Meunier, B. Oxidative Damage Generated by an Oxo-Metalloporphyrin onto the Human Telomeric Sequence. Biochemistry 2000, 39, 9514. [CrossRef]

67. Shi, D.F.; Wheelhouse, R.T.; Sun, D.; Hurley, L.H. Quadruplex-interactive agents as telomerase inhibitors:Synthesis of porphyrins and structure-activity relationship for the inhibition of telomerase. J. Med. Chem. 2001, 44, 4509. [CrossRef] 
68. Keating, L.R.; Szalai, V.A. Parallel-stranded guanine quadruplex interactions with a copper cationic porphyrin. Biochemistry 2004, 43, 15891. [CrossRef]

69. Evans, S.E.; Mendez, M.A.; Turner, K.B.; Keating, L.R.; Grimes, R.T.; Melchoir, S.; Szalai, V.A. End-stacking of copper cationic porphyrins on parallel—Stranded guanine quadruplexes. J. Biol. Inorg. Chem. 2007, 12, 1235. [CrossRef] [PubMed]

70. DuPont, J.I.; Henderson, K.L.; Metz, A.; Le, V.H.; Emerson, J.P.; Lewis, E.A. Calorimetric and spectroscopic investigations of the binding of metallated porphyrins to G-quadruplex DNA. Biochim. Biophys. Acta 2016, 1860, 902. [CrossRef] [PubMed]

71. Dixon, I.M.; Lopez, F.; Esteve, J.P.; Tejera, A.M.; Blasco, M.A.; Pratviel, G.; Meunier, B. Porphyrin Derivatives for Telomere Binding and Telomerase Inhibition. ChemBioChem 2005, 6, 123-132. [CrossRef] [PubMed]

72. Dixon, I.M.; Lopez, F.; Tejera, A.M.; Esteve, J.P.; Blasco, M.A.; Pratviel, G.; Meunier, B. A G-quadruplex ligand with 10000-fold selectivity over duplex DNA. J. Am. Chem. Soc. 2007, 129, 1502. [CrossRef] [PubMed]

73. Sabater, L.; Fang, P.-J.; Chang, C.-F.; Rache, A.; Prado, E.; Dejeu, J.; Garofalo, A.; Lin, J.-H.; Mergny, J.-L.; Defrancq, E.; et al. Cobalt(III)porphyrin to target G-quadruplex DNA. Dalton Trans. 2015, 44, 3701. [CrossRef] [PubMed]

74. Dejeu, J.; Lavergne, T.; Nora, J.D.; Defrancq, E.; Pratviel, G. Binding of mettaloporphyrins of G-Quadruplex: The role of central metal. Inorg. Chimica Acta 2016, 452, 98. [CrossRef]

75. Pan, J.; Zhang, S. Interaction between cationic zinc porphyrin and lead ion induced telomeric guanine quadruplexes: Evidence for end-stacking. J. Biol. Inorg. Chem. 2009, 14, 401. [CrossRef]

76. Bhattacharjee, A.J.; Ahluwalia, K.; Taylor, S.; Jin, O.; Nicoludis, J.M.; Buscaglia, R.; Chaires, J.B.; Kornfilt, D.J.P.; Marquard, D.G.S.; Yatsunyk, L.A. Induction of G-quadruplex DNA structure by Zn(II) 5,10,15,20-tetrakis(N-methyl-4-pyridyl)porphyrin. Biochimie 2011, 93, 1297. [CrossRef]

77. Sabharwal, N.C.; Mendoza, O.; Nicoludis, J.M.; Ruan, T.; Mergny, J.L.; Yatsunyk, L.A. Investigation of the interactions between $\mathrm{Pt}(\mathrm{II})$ and $\mathrm{Pd}(\mathrm{II})$ derivatives of 5,10,15,20-tetrakis (N-methyl-4-pyridyl) porphyrin and G-quadruplex DNA. J. Biol. Inorg. Chem. 2016, 21, 227. [CrossRef]

78. Yao, X.; Song, D.; Qin, T.; Yang, C.; Yu, Z.; Li, X.; Liu, K.; Su, H. Interaction between G-Quadruplex and Zinc Cationic Porphyrin: The Role of the Axial Water. Sci Rep. 2017, 7, 10951. [CrossRef] [PubMed]

79. Pipier, A.; Rache, A.; Modeste, C.; Amrane, S.; Mothes-Martin, E.; Stigliani, J.-L.; Calsou, P.; Stigliani, J.-L.; Pratviel, G.; Gomez, D. G-Quadruplex binding optimization by gold(III) insertion into the center of a porphyrin. Dalton Trans. 2019, 48, 6091. [CrossRef]

80. Rundstadler, T.; Mothes, E.; Amrane, S.; Stigliani, J.-L.; Verhaeghe, P.; Pratviel, G. Gold(III) porphyrins: Synthesis and interaction with G-quadruplex DNA. J. Inorg. Biochem. 2021, 223, 111551. [CrossRef] [PubMed]

81. Tovmasyan, A.; Babayan, N.; Poghosyan, D.; Margaryan, K.; Harutyunyan, B.; Grigoryan, R.; Sarkisyan, N.; Spasojevic, I.; Mamyan, S.; Sahakyan, L.; et al. Novel amphiphilic cationic porphyrin and its Ag(II) complex as potential anticancer agents. J. Inorg. Biochem. 2014, 140, 94. [CrossRef] [PubMed]

82. Schultze, P.; Smith, F.W.; Feigon, J. Refined solution structure of the dimeric quadruplex formed from the Oxytricha telomeric oligonucleotide d(GGGGTTTTGGGG). Structure 1994, 2, 221. [CrossRef]

83. Wang, Y.; Patel, D.J. Solution structure of the human telomeric repeat d[AG3(T2AG3)3] G-tetraplex. Structure 1993, 1, 263. [CrossRef]

84. Parkinson, G.N.; Lee, M.P.H.; Neidle, S. Crystal structure of parallel quadruplexes from human telomeric DNA. Nature 2002, 417, 876. [CrossRef]

85. Wei, C.Y.; Jia, G.Q.; Yuan, J.L.; Feng, Z.C.; Li, C. A spectroscopic study on the interactions of porphyrin with G-quadruplex DNAs. Biochem 2006, 45, 6681. [CrossRef]

86. Sun, Y.; Ji, F.; Liu, R.; Lin, J.; Xu, Q.; Gao, C. Interaction mechanism of 2-aminobenzothiazole with herring sperm DNA. J. Lumin. 2012, 132, 507. [CrossRef]

87. Bhattacharjee, S.; Sengupta, P.K.; Bhowmik, S. Exploring the preferential interaction of quercetin with VEGF promoter Gquadruplex DNA and construction of a pH-dependent DNA-based logic gate. RSC Adv. 2017, 7, 37230. [CrossRef]

88. Haq, I.; Trent, J.O.; Chowdhry, B.Z.; Jenkins, T.C. Intercalative G-tetraplex stabilization of telomeric DNA by a cationic porphyrin. J. Am. Chem. Soc. 1999, 121, 1768. [CrossRef] 